\title{
Growth volatility and financial liberalization ${ }^{\text {is }}$
}

\author{
Geert Bekaert $^{\text {a,b }}$, Campbell R. Harvey ${ }^{\text {b,c,* }}$, Christian Lundblad ${ }^{\text {d }}$ \\ ${ }^{a}$ Columbia University, New York, NY 10027, USA \\ ${ }^{\mathrm{b}}$ National Bureau of Economic Research, Cambridge, MA 02138, USA \\ ${ }^{\text {c }}$ Fuqua School of Business, Duke University, Durham, NC 27708, USA \\ ${ }^{\mathrm{d}}$ University of North Carolina, Chapel Hill, NC 27514, USA
}

\begin{abstract}
We examine the effects of both equity market liberalization and capital account openness on real consumption growth variability. We show that financial liberalization is mostly associated with lower consumption growth volatility. Our results are robust, surviving controls for business-cycle effects, economic and financial development, the quality of institutions, and other variables. Countries that have more open capital accounts experience a greater reduction in consumption growth volatility after equity market openings. We also find that financial liberalizations are associated with declines in the ratio of consumption growth volatility to GDP growth volatility, suggesting improved risk sharing. Our results are weaker for liberalizing emerging markets but we never observe a significant increase in real volatility. Moreover, we demonstrate significant differences in the volatility response depending on the size of the banking and government sectors and certain institutional factors.
\end{abstract}

(c) 2006 Elsevier Ltd. All rights reserved.

JEL classification: E32; F30; F36; F43; G15; G18; G28

\footnotetext{
Based on the keynote address at Cass Business School/Journal of International Money and Finance Conference on Emerging Markets Finance, May 6, 2005 in London. We thank Susan Collins for inspiring this paper. We appreciate the comments of Andrew Frankel, Blake LeBaron, Marco Del Negro, Vihang Errunza, Yasushi Hamao, Roberto Rigobon, Lubos Pastor, Sergio Schmukler and seminar participants at the Atlanta Federal Reserve Bank, Cass Business School, Fordham University, University of Leuven (Belgium), London School of Economics, McGill University, MIT, New York University, University of Porto, ISCTE Lisbon, HEC Lausanne, Yale University (School of Management), the National Bank of Belgium Conference on Efficiency and Stability in an Evolving Financial System, the ECB Conference on Global Financial Integration, Stability, and Business Cycles: Exploring the Links, PACAP, Taipei, the European Finance Association meetings in Berlin, and the American Economic Association meetings in Washington, D.C. This paper was written while Lundblad was at Indiana University in Bloomington.

* Corresponding author. Tel.: +1 9196607768.

E-mail address: cam.harvey@duke.edu (C.R. Harvey).
} 


\section{Introduction}

Is the cost to a country for opening its financial markets to foreign portfolio investment increased economic volatility? Our research suggests the answer is no. Our research question bridges at least two distinct literatures.

First, there is a heated debate in the growth and development economics literature on the costs and benefits of financial liberalization. ${ }^{1}$ Research focusing on capital account openness finds mixed results (see Eichengreen, 2001 for a survey), but articles focusing on equity market liberalization typically find significant positive average growth effects from liberalization (see, for example, Bekaert et al., 2001, 2005).

Policy makers in developing countries, however, are interested in more than the average effect. The crises in Mexico and South East Asia have focused attention on the potentially disruptive effects of foreign speculative capital that may leave at a whim and abruptly throw whole countries or regions into recession. There is a perception that foreign capital not only increases volatility in the financial markets, but also in the real economy, and that such volatility is not desired (see Stiglitz, 2000; Agenor, 2003). The perceived disadvantages of unbridled capital flows have recently brought back proposals for a Tobin tax on cross-border capital flows even between developed markets (see Eichengreen et al., 1995).

Second, there is an extensive literature on the benefits of international risk sharing. This literature explicitly recognizes that open capital markets lead to international risk sharing, which should improve welfare. Due to a multitude of reasons such as home asset preference, imperfect market integration, and incomplete insurance markets, the benefits of international risk sharing are not realized and, consequently, the main question the literature attempts to answer is how large these benefits potentially would be. Most studies use consumption-based endowment models to measure the utility benefit of moving from the current situation to a situation of optimal risk sharing. A major component of the benefits of international risk sharing is the reduction of the variability of consumption growth, and often level effects are simply ignored (Obstfeld, 1994 is an important exception). So far, there appears to be no consensus about the extent of the benefits of international risk sharing (see van Wincoop, 1999; Lewis, 1999).

Our study contributes to this debate by testing directly whether consumption growth volatility changes after financial liberalization. If there are genuine benefits to international risk sharing, we expect to observe reduced consumption growth volatility. If instead, financial liberalization leads to increased financial fragility and crises (Furman and Stiglitz, 1998), we expect to observe increased volatility. Of course, the presence of a positive level effect implies that finding no significant volatility effect generally suffices to conclude that liberalizations improved welfare. Importantly, we can conduct this test with minimal parametric assumptions.

Our article contains five parts.

First, we measure financial liberalization. Our first measure narrowly focuses on the equity market which should be particularly relevant for risk sharing, and relies on the measures developed by Bekaert and Harvey (2000a). We also want to more broadly examine capital account openness and we use the standard IMF measure as well as measure compiled by Quinn (1997),

\footnotetext{
${ }^{1}$ We use this term to indicate any policy decision that opens up capital markets to foreign investment (or allows domestic residents to make use of foreign capital markets). We do not refer to reforms focussed on deregulating domestic capital markets.
} 
which corrects for the degree of openness. We describe these measures, some initial analysis and the empirical framework in Section 2.

Second, we run panel regressions of consumption growth volatility on the liberalization measures and controls using two different samples. The first sample only includes liberalizing countries and explicitly measures a temporal effect. The second sample also considers countries that are always open or closed to foreign investment. This sample provides further insights on the cross-sectional determinants of macroeconomic volatility, including the degree of capital account openness. Section 3 contains the main results, showing the liberalization effect in the presence of controls for economic development, the size of the government sector, the presence and extent of social security benefits, time trends etc., including a large number of robustness checks. In a sample totally focusing on the temporal effect, we never observe a significant increase in volatility. Mostly, the volatility effect is insignificantly different from zero, but it is sometimes significantly negative as well, especially when measured with indicators that take the degree of liberalization or openness into account. The hypothesis that the volatility increase is larger than $1 \%$ is invariably strongly rejected. In a large cross-section, equity market liberalization and capital account openness (when measured properly) are associated with substantially lower consumption growth variability. It is even the case that the effect of equity market liberalization is larger for countries with a relatively more open capital account.

Third, Section 4 deals with potential endogeneity and simultaneity problems. Is the liberalization strategically timed when volatility is expected to change? Or does the liberalization effect reflect the effects of simultaneous reforms, for example regarding macroeconomic policy or the domestic financial sector? In this section, we control for the presence of macroeconomic imbalances, financial development, and more generally, the quality of institutions. Our findings remain robust.

Fourth, the inability to find a significant effect among the liberalizing countries potentially hides important cross-sectional differences among the liberalization response for different countries. A substantial interaction analysis shows that countries with relatively large government sectors and developed banking sectors experience significant reductions in volatility but countries with poor investor protection experience significant increases in volatility.

Fifth, because liberalization may affect both the variability of the shocks a country faces and its ability to smooth shocks over time, we also examine the impact of liberalization on GDP growth volatility and on the ratio of consumption growth volatility to GDP growth volatility (a measure of production variability). While the development literature is primarily interested in the first measure (see Easterly et al., 2001), the second measure is more relevant for the risk sharing literature. Ex-ante, the two measures may yield different results. We would expect that the ability to share income risk through international capital markets should improve consumption smoothing and lower consumption growth volatility for a given level of output volatility. However, the effects on output growth volatility are hard to predict because financial openness may promote specialization and increase macroeconomic vulnerability, but may also bring about a more diversified industrial structure. We find in Section 5 that the GDP volatility effects are similar to the consumption growth variability effects, but weaker, leading to an almost always significantly lower volatility ratio. This evidence points towards an improved ability to smooth shocks post-liberalization. In Section 6, we confirm our results to be robust to the use of an idiosyncratic consumption growth measure that strips out predictable and common components in consumption growth.

Some concluding remarks are offered in Section 7. An appendix describes our econometric framework. 


\section{Empirical model and data description}

\subsection{A simple econometric model}

Denote the logarithmic growth in real consumption per capita for country $i$ between year $t$ and $t+1$ as $y_{i, t+1}$. We define the growth rate variability, $\operatorname{Stdev}_{i, t+5}$, as the standard deviation of the consumption growth rate estimated over 5 years, that is, with $\left\{y_{i, t+j}\right\}, j=1, \ldots, 5$. $^{2}$ In the tradition of the growth literature, our primary regressions can be specified as follows:

$$
\operatorname{Stdev}_{i, t+5}=\gamma^{\prime} \mathbf{Q}_{i, t}+\alpha \operatorname{Lib}_{i, t}+\varepsilon_{i, t+5}
$$

Similar to standard growth regressions, the $\mathbf{Q}_{i, t}$ variables control for different levels of consumption growth variability across countries. Our main focus is the effect, $\alpha$, of equity market liberalization or capital account openness, denoted by $\mathrm{Lib}_{i, t}$, on growth variability. We discuss the construction of this variable in more detail in the next section.

Most importantly, in addition to cross-country information, this econometric method facilitates the exploration of the time-series dimension of growth variability inherent in the liberalization process. To maximize the time-series content in our regression, we use overlapping data and deal with the resulting moving average component in the residuals by adjusting the standard errors as a cross-sectional extension to Hansen and Hodrick (1980). ${ }^{3}$ We estimate this system with pre-determined regressors, using a GMM estimator more fully described in Bekaert et al. (2001). Our main estimator corrects for country-specific heteroskedasticity and we can also accommodate SUR effects.

In an Appendix, we describe a Monte Carlo experiment that examines the accuracy of the volatility change estimator, and the size and power of test statistics for $\hat{a}$. We estimate a cross-sectional model on one-year consumption growth rates with an average growth effect of liberalization and with (alternative) and without (null) a volatility effect. When we construct the five-year standard deviation measure from the simulation and run our regression on a liberalization indicator, we find the estimator to be unbiased under the null and the $t$-test for significance to have considerable power. However, the $t$-statistic (in absolute magnitude) needed to reach 5\% significance must be larger than 3.00 instead of the standard 1.96 under a normal distribution.

\subsection{Measuring liberalization}

\subsubsection{Equity market liberalization}

There are many ways to measure liberalization. An important distinction is between de facto and de jure financial openness or liberalization (see Aizenman and Noy, 2004; Bekaert et al., 2002a,b; Prasad et al., 2004 for recent discussions). The break points in equity flows in Bekaert

\footnotetext{
${ }^{2}$ We also constructed an alternative measure of volatility based on the high-low range of consumption growth over the observed 5 years. This measure avoids the implicit estimation of the mean inherent in standard deviation calculations. However, the range measure is highly correlated with the standard deviation, and using the range in the regression produces qualitatively very similar results. Furthermore, we verified the robustness of our results to changing from a five-year window to a seven-year window. These results are available on request.

${ }^{3}$ The Hansen-Hodrick (1980) estimator does not guarantee positive semi-definiteness of the weighting matrix. If the matrix turns out to be not positive semi-definite, we increase the lag length by 1 and use the Newey-West (1987) estimator.
} 
and Harvey (2000b) and the foreign asset/liability ratios in Lane and Milesi-Ferretti (2001) are examples of de facto measures. Because we are interested in the effects of changes in policy, we consider two de jure measures of liberalization.

The first measure, the "Official Liberalization" indicator, takes a value of one when the equity market is officially (by regulation) liberalized; otherwise, it takes a value of zero. Official liberalization dates are drawn from the chronology presented in Bekaert and Harvey (2005) and expanded to all the countries considered in this study in Bekaert et al. (2005).

Our second measure of equity market liberalization, "Intensity" takes into account that most liberalizations are not one-time events, they are gradual and may not be comprehensive at first. Our intensity indicator follows Bekaert (1995) and Edison and Warnock (2003), who take the ratio of the market capitalizations of the constituent members of the IFC investable and the IFC global indices for each country. In this context, a ratio of one means that all of the stocks are available to foreign investors. For example, during the 1990s Korea lifted foreign ownership restrictions in a number of steps leading to an intensity indicator that gradually moved from zero to one. For both indicators, fully segmented countries are assumed to have an indicator value of zero, and fully liberalized countries are assumed to have an indicator value of one.

Whereas we phrase our discussion in terms of restrictions on inflows, most liberalizations relax inflows and outflows simultaneously, e.g. Mathieson and Rojaz-Suarez (1993). Relaxing outflows is essential to realize risk sharing benefits.

\subsubsection{Capital account openness}

We consider two measures of capital account openness. Our first measure is from IMF's Annual Report on Exchange Arrangements and Exchange Restrictions (AREAER). The IMF publication details several categories of information, mostly on current account restrictions. The capital account openness dummy variable takes on a value of zero if the country has at least one restriction in the "restrictions on payments for the capital account transactions" category.

Eichengreen (2001) has criticized the IMF capital account measure for being too coarse and therefore uninformative. The second measure of capital account openness is from Quinn (1997) and Quinn and Toyoda (2003) and is also created from the annual volume published by the IMF's AREAER. However, in contrast to the binary IMF indicator, Quinn's openness measure is scored from 0 to 4 , with 4 representing a fully open economy. Quinn grades capital payments and receipts separately on a scale of 0 to 2 ( 0.5 increments), and then adds the two. The scale is determined as follows: $0=$ approval required and rarely granted; $0.5=$ approval required and sometimes granted; $1.0=$ no restrictions but official approval required (and frequently granted) plus transaction is taxed; $1.5=$ no official approval needed but transaction may be taxed; and $2.0=$ free. The Quinn measure picks up the degree to which the capital account is open and is analogous to our intensity indicator for equity market liberalization. We transform the Quinn measure into a 0 to 1 scale.

\subsubsection{Other data}

Our macroeconomic and financial data, spanning 1980-2000, are drawn from a number of sources detailed in Table 1. In our empirical exercises, we consider two different country samples. Sample I represents the 95 countries where all the main macroeconomic variables are available. Sample II includes the 40 countries that have experienced an equity market liberalization. Most of these countries are emerging markets but the sample also includes New Zealand and Japan. In sample I, the identification of the liberalization effect on growth volatility comes from both cross-sectional (segmented versus liberalized countries) and temporal (preversus post-liberalization) variations. 
Table 1

Description of the variables

\begin{tabular}{ll}
\hline Variable & Description \\
\hline & Dating equity market liberalization \\
Official equity market & $\begin{array}{l}\text { Corresponding to a date of formal regulatory change after which foreign investors officially } \\
\text { have the opportunity to invest in domestic equity securities. See http://www.duke.edu/ } \\
\end{array}$ \\
& $\sim$ charvey/chronology.htm for more details. For the liberalizing countries, the associated \\
& official liberalization indicator takes a value of one when the equity market is officially \\
& countries are assumed to have an indicator value of zero, and fully liberalized countries are \\
& assumed to have an indicator value of one.
\end{tabular}

Intensity equity market liberalization indicator

IMF capital account liberalization indicator

Quinn capital account liberalization indicator

Gross domestic product (GDP) growth Consumption growth

\section{Initial GDP \\ Government consumption/GDP}

Secondary school enrollment
The intensity measure is based on the ratio of the market capitalization of the constituent firms comprising the IFC Investable index to those that comprise the IFC Global index for each country. The IFC Global index is designed to represent the overall market portfolio for each country, whereas the IFC Investable index is designed to represent a portfolio of domestic equities that are available to foreign investors. A ratio of one means that all of the stocks are available to foreign investors. Fully segmented countries have an intensity measure of zero, and fully liberalized countries have an intensity measure of one. Liberalizing countries (denoted "frontier" by Standard and Poor's EMDB) receive an intensity measure of zero since they do not have an "investable" index.

\section{Other important dates}

We measure capital account openness by employing the IMF's Annual Report on Exchange Arrangements and Exchange Restrictions (AREAER). The capital account liberalization indicator takes a value of zero if the country has at least one restriction in the "restrictions on payments for the capital account transaction" category.

Quinn's capital account openness measure is also created from the text of the annual AREAER volume. Quinn's openness measure is scored $0-4$, in half integer units, with 4 representing a fully open economy. The measure is available for 76 countries in our study. We transform each measure into a $0-1$ scale.

\section{Macroeconomic and demographic measures}

Growth of real per capita gross domestic product. Available for all countries from 1980 through 2000. Source: World Bank Development Indicators CD-ROM.

Growth of real per capita private consumption, the market value of all goods and services, including durable products purchased or received as income in kind by households and nonprofit institutions. For those few years for which consumption figures are missing, we fill in data by taking the consumption level implied by the per capita GDP level, assuming the consumption/GDP ratio is unchanged from the previous year. We added updated consumption data for Botswana due to an apparent data error (www.worldbank.com). Available for all countries from 1980 through 2000. Source: World Bank Development Indicators CD-ROM.

Logarithm of real per capita gross domestic product in 1980.

Government consumption divided by gross domestic product. General government final consumption expenditure includes all government current expenditures for purchases of goods and services. Available for all countries from 1980 through 2000. Source: World Bank Development Indicators CD-ROM.

Secondary school enrollment ratio is the ratio of total enrollment to the population of the age group that officially corresponds to the secondary level of education. Available for all countries from 1980 through 2000. Source: World Bank Development Indicators CD-ROM.

(continued on next page) 
Table 1 (continued)

\begin{tabular}{ll}
\hline Variable & Description \\
\hline Population growth & Growth rate of total population which counts all residents regardless of legal status or \\
& citizenship. Available for all countries from 1980 through 2000. Source: World Bank \\
Development Indicators CD-ROM.
\end{tabular}

Log life expectancy

Life expectancy at birth indicates the number of years a newborn infant would live if prevailing patterns of mortality at the time of its birth were to stay the same throughout its life. Available for all countries from 1980 through 2000. Source: World Bank Development Indicators CD-ROM.

\section{Macroeconomic reforms}

\section{Trade/GDP}

Inflation

Black market premium

Quality of institutions

Corruption

Law and Order

Bureaucratic Quality

\section{Conflict}

Internal Conflict
The trade dependency ratio is the sum of exports and imports of goods and services measured as a share of gross domestic product. Available for all countries from 1980 through 2000. Source: World Bank Development Indicators CD-ROM.

Inflation as measured by the log annual growth rate of the gross domestic product implicit deflator. We use the CPI if the GDP-deflator is not available. Available for all countries from 1980 through 2000. Source: World Bank Development Indicators CD-ROM.

The black market premium is defined as (parallel FXrate/official FXrate - 1)100, where parallel FXrate is the black market rate. Available for all countries from 1980 through 2000. Source: Easterly et al. (2001).

The sum of ICRG subcomponents: Corruption, Law and Order, and Bureaucratic Quality.

The PRS measure of corruption within the political system reflects actual or potential corruption in the form of excessive patronage, nepotism, job reservations, "favor-forfavors", secret party funding, and suspiciously close ties between politics and business. In PRS's view these sorts of corruption pose risk to foreign business, potentially leading to popular discontent, unrealistic and inefficient controls on the state economy, and encourage the development of the black market.

PRS assesses Law and Order, separately. The Law subcomponent is an assessment of the strength and impartiality of the legal system, while the Order subcomponent is an assessment of popular observance of the law.

PRS's bureaucratic quality index gives high points to countries where the bureaucracy has the strength and expertise to govern without drastic changes in policy or interruptions in government services. In these low risk countries, the bureaucracy tends to be somewhat autonomous from political pressure and to have an established mechanism for recruitment and training. Countries that lack the cushioning effect of a strong bureaucracy receive low points because a change in government tends to be traumatic in terms of policy formulation and day-to-day administrative functions.

The sum of ICRG subcomponents: internal conflict, external conflict, religious tensions, ethnic tensions.

This is an assessment of political violence in the country and its actual or potential impact on governance. The highest rating is given to those countries where there is no armed opposition to the government and the government does not indulge in arbitrary violence against its own people. The lowest rating is given to a country embroiled in an on-going civil war. The intermediate ratings are awarded on the basis of whether the threat posed is to government and business or only business; whether acts of violence are carried out for a political objective; whether such groups are composed of a few individuals with little support, or are well organized movements operating with the tacit support of the people they purport to represent; whether acts of violence are sporadic or sustained; and whether they are restricted to a particular locality or region, or are carried out nationwide. 
Table 1 (continued)

\begin{tabular}{|c|c|}
\hline Variable & Description \\
\hline External conflict & $\begin{array}{l}\text { The external conflict measure is an assessment of the risk to both the incumbent } \\
\text { government and inward investment. It ranges from trade restrictions and embargoes, } \\
\text { whether imposed by a single country, a group of countries, or the whole international } \\
\text { community, through geopolitical disputes, armed threats, exchanges of fire on borders, } \\
\text { border incursions, foreign-supported insurgency, and full-scale warfare. }\end{array}$ \\
\hline Religion in politics & $\begin{array}{l}\text { Religious tensions may stem from the domination of society and/or governance by a } \\
\text { single religious group that seeks to replace civil law by religious law and to exclude } \\
\text { other religions from the political and/or social process; the desire of a single religious } \\
\text { group to dominate governance; the suppression of religious freedom; the desire of a } \\
\text { religious group to express its own identity, separate from the country as a whole. }\end{array}$ \\
\hline
\end{tabular}

Ethnic tensions

Private credit/GDP

Equity market turnover

\section{MCAP/GDP}

Legal origin

Judicial efficiency

Speed of judicial process

Economic risk rating

Social security index
This component measures the degree of tension within a country attributable to racial, nationality, or language divisions.

\section{Financial sector}

Credit to private sector refers to financial resources provided to the private sector, such as through loans, purchases of non-equity securities, and trade credits and other accounts receivable that establish a claim for repayment. Available for all countries from 1980 through 2000. Source: World Bank Development Indicators CD-ROM.

The ratio of equity market value traded to the market capitalization. The data are available for 50 countries from 1980 through 2000. Source: Standard and Poor's/ International Finance Corporation's Emerging Stock Markets Factbook.

The ratio of equity market capitalization to gross domestic product. The data are available for 50 countries from 1980 through 2000. Source: Standard and Poor's/ International Finance Corporation's Emerging Stock Markets Factbook.

\section{Legal environment}

Identifies the legal origin of the company law or commercial code of each country (English, French, Socialist, German, Scandinavian). Legal origin is available for all countries. This variable is purely cross-sectional, and available for all countries. Source: La Porta et al. (1998).

Assessment of the "efficiency and integrity of the legal environment as it affects business, particularly foreign firms" produced by the country risk rating agency Business International Corp. Average between 1980 and 1983. Scale from 0 to 10, with lower scores, lower efficiency levels. This variable is purely cross-sectional, and available for 47 countries. Source: La Porta et al. (1998).

The total estimated speed in calendar days of the procedure (to evict a tenant for nonpayment of rent or to collect a bounced check) under the factual and procedural assumptions provided. It equals the sum of (i) duration until completion of service of process, (ii) duration of trial, and (iii) duration of enforcement. This variable is purely cross-sectional, and available for 69 countries. Source: Djankov et al. (2003).

\section{Macroeconomic and demographic variables}

The value of the the Political Risk Service (PRS) Group's economic risk indicator (which ranges between 0 and 50). The risk rating is a combination of 5 subcomponents: GDP levels and growth, respectively, inflation, balanced budgets, and the current account.

From Botero et al. (2004), measures social security benefits: (i) old age, disability and death benefits; (ii) sickness and health benefits; and (iii) unemployment benefits. Each subgroup is quantitavely scored, and summed to create the overall index.

All data are employed at the annual frequency. 


\subsubsection{Summary analysis}

Fig. 1 contains a summary analysis of the volatility effect. For the group of 40 liberalizing countries, 26 countries experience a decrease in consumption growth volatility and 14 countries experience an increase after liberalization. The computations use 5 years of consumption growth before and 5 years after the liberalization. On average, consumption growth volatility decreases after liberalizations, from 0.052 to 0.045 . However, an equally weighted average might give undue weight to some small countries. If we weight countries by their relative GDP, the average volatility decreases from 0.047 to 0.033 . This difference is not statistically significant.

Importantly, this summary analysis is unconditional: in the next section, we control for other forces that might impact growth volatility.

\section{Consumption growth volatility and financial liberalization}

\subsection{Equity market liberalization and growth variability}

In Table 2, we explore the role of control variables in the relation between consumption growth volatility and equity market liberalization. In the first panel, we run a fixed effects regression examining the 40 country sample. There is a decrease in consumption growth volatility of 0.017 or $1.7 \%$, however, this is only 1.5 standard errors from zero.

From the perspective of the development literature, this result is in fact quite important because the perception is that liberalizations are associated with strong increases in real volatility. Suppose the null hypothesis is that the increase in volatility is greater than $1 \%$. It is unlikely that a $1 \%$ increase in volatility would have substantial welfare effects. Our estimate is 2.45 standard errors below $1 \%$.

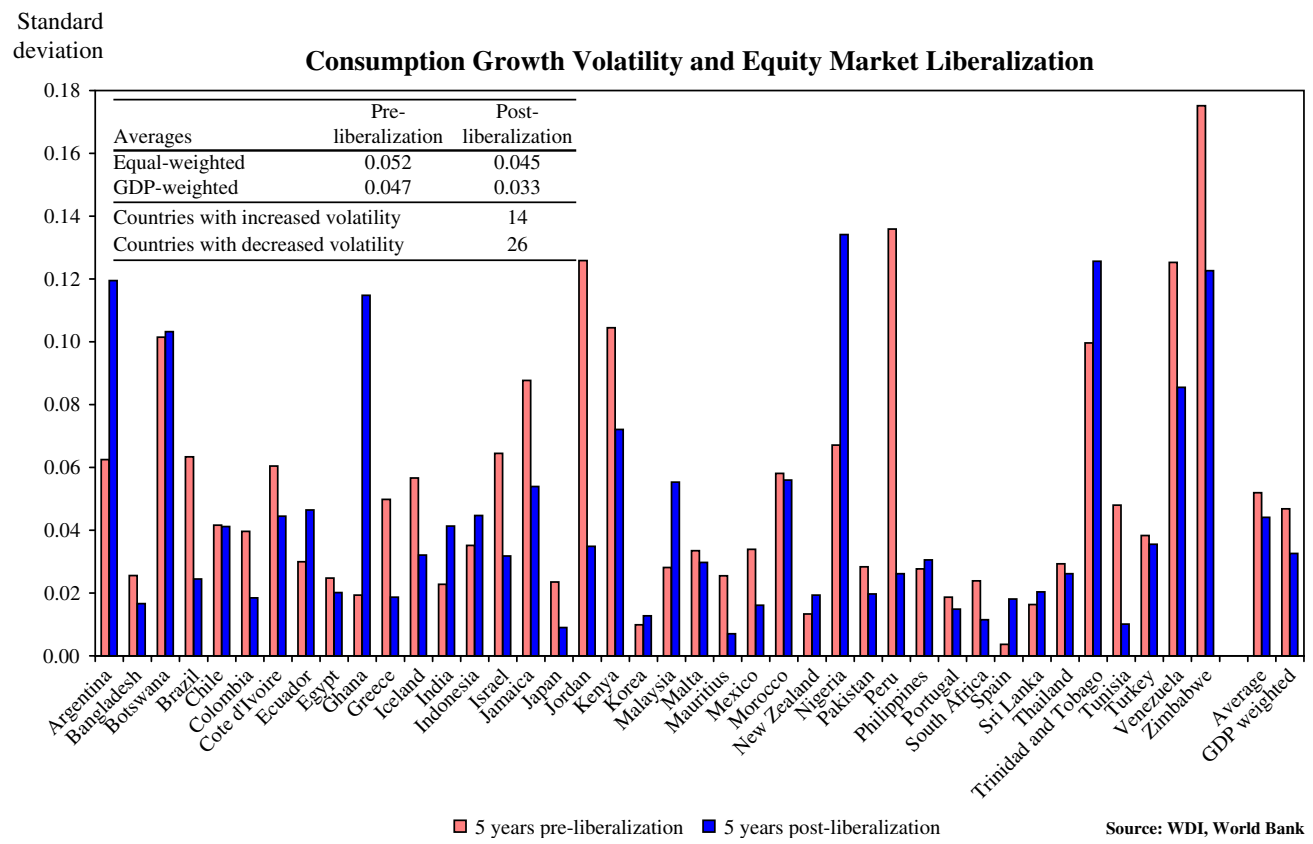

Fig. 1. Consumption growth volatility and equity market liberalization. 
Table 2

Consumption growth volatility and equity market liberalization

\begin{tabular}{|c|c|c|c|c|c|c|c|c|c|}
\hline $\begin{array}{l}\text { Number of } \\
\text { countries }\end{array}$ & Constant & $\begin{array}{l}\text { Initial } \\
\log (\text { GDP })\end{array}$ & $\begin{array}{l}\text { Gov/ } \\
\text { GDP }\end{array}$ & $\begin{array}{l}\text { Secondary } \\
\text { school } \\
\text { enrollment }\end{array}$ & $\log ($ life $)$ & $\begin{array}{l}\text { Population } \\
\text { growth }\end{array}$ & $\begin{array}{l}\text { Official } \\
\text { liberalization } \\
\text { indicator }\end{array}$ & $\begin{array}{l}\text { Fixed } \\
\text { effects }\end{array}$ & $\begin{array}{l}\text { Time } \\
\text { effects }\end{array}$ \\
\hline \multicolumn{10}{|c|}{ Panel A: Fixed effect estimation } \\
\hline 40 & & & & & & & $\begin{array}{r}-0.0017 \\
(0.0011)\end{array}$ & Yes & No \\
\hline \multicolumn{10}{|c|}{ Panel B: Control variables } \\
\hline 95 & $\begin{array}{c}0.2152 \\
(0.0493)\end{array}$ & $\begin{array}{r}-0.0039 \\
(0.0015)\end{array}$ & $\begin{array}{c}0.1948 \\
(0.0253)\end{array}$ & $\begin{array}{r}-0.0123 \\
(0.0084)\end{array}$ & $\begin{array}{r}-0.0375 \\
(0.0131)\end{array}$ & $\begin{array}{c}0.0603 \\
(0.0946)\end{array}$ & $\begin{array}{r}-0.0192 \\
(0.0028)\end{array}$ & No & No \\
\hline 40 & $\begin{array}{r}-0.1015 \\
(0.0943)\end{array}$ & $\begin{array}{c}0.0007 \\
(0.0020)\end{array}$ & $\begin{array}{c}0.0762 \\
(0.0326)\end{array}$ & $\begin{array}{r}-0.0515 \\
(0.0110)\end{array}$ & $\begin{array}{c}0.0357 \\
(0.0243)\end{array}$ & $\begin{array}{c}0.4105 \\
(0.1858)\end{array}$ & $\begin{array}{c}0.0003 \\
(0.0027)\end{array}$ & No & No \\
\hline \multicolumn{10}{|c|}{ Panel C: Time effects } \\
\hline 95 & $\begin{array}{c}0.1817 \\
(0.0513)\end{array}$ & $\begin{array}{r}-0.0040 \\
(0.0018)\end{array}$ & $\begin{array}{c}0.1874 \\
(0.0264)\end{array}$ & $\begin{array}{r}-0.0157 \\
(0.0085)\end{array}$ & $\begin{array}{r}-0.0301 \\
(0.0138)\end{array}$ & $\begin{array}{c}0.1344 \\
(0.0975)\end{array}$ & $\begin{array}{r}-0.0162 \\
(0.0030)\end{array}$ & No & Trend \\
\hline 95 & & $\begin{array}{r}-0.0060 \\
(0.0017)\end{array}$ & $\begin{array}{c}0.2227 \\
(0.0314)\end{array}$ & $\begin{array}{r}-0.0172 \\
(0.0085)\end{array}$ & $\begin{array}{r}-0.0172 \\
(0.0154)\end{array}$ & $\begin{array}{c}0.1580 \\
(0.0881)\end{array}$ & $\begin{array}{r}-0.0124 \\
(0.0029)\end{array}$ & No & $\begin{array}{l}\text { Time } \\
\text { dummies }\end{array}$ \\
\hline 40 & $\begin{array}{r}-0.0742 \\
(0.0969)\end{array}$ & $\begin{array}{c}0.0012 \\
(0.0022)\end{array}$ & $\begin{array}{c}0.0766 \\
(0.0326)\end{array}$ & $\begin{array}{r}-0.0553 \\
(0.0110)\end{array}$ & $\begin{array}{c}0.0273 \\
(0.0254)\end{array}$ & $\begin{array}{c}0.4334 \\
(0.1871)\end{array}$ & $\begin{array}{r}-0.0018 \\
(0.0033)\end{array}$ & No & Trend \\
\hline 40 & & $\begin{array}{c}0.0027 \\
(0.0021)\end{array}$ & $\begin{array}{r}-0.0065 \\
(0.0323)\end{array}$ & $\begin{array}{r}-0.0484 \\
(0.0101)\end{array}$ & $\begin{array}{r}-0.0215 \\
(0.0226)\end{array}$ & $\begin{array}{c}0.3191 \\
(0.1756)\end{array}$ & $\begin{array}{r}-0.0013 \\
(0.0030)\end{array}$ & No & $\begin{array}{l}\text { Time } \\
\text { dummies }\end{array}$ \\
\hline
\end{tabular}

The dependent variable is the five-year standard deviation of the real consumption growth rate calculated over 1980-2000. Table 1 provides a detailed description for each variable. The last column indicates the inclusion of a time adjustment (time trend or time dummies). All standard errors in parentheses provide a correction for cross-sectional heteroskedasticity and account for the overlapping nature of the data.

The next panel in Table 2 considers a set of control variables that are typically used in level growth regressions: initial GDP (1980), government consumption to GDP, secondary school enrollment, population growth, and life expectancy.

We expect more developed economies to have a more diversified industrial structure and more sophisticated macroeconomic policies that help reduce the variability of growth. Both life expectancy and secondary school enrollment are correlated with economic development. A large government sector could be an indication of large macroeconomic imbalances and economies that do not let capital be allocated to investments using private market signals. If this were the case, we would expect variability to be positively correlated with a larger government sector. A large government sector could also reflect the existence of a large welfare state with sophisticated policies to smooth out macroeconomic shocks. If that is true, we expect lower variability for a larger government sector.

The coefficient on secondary school enrollment is negative for both samples but only significant for the 40 country sample suggesting that countries with high human capital have lower consumption growth variability. The coefficients on the life expectancy and initial GDP variables have inconsistent signs in the two samples. The coefficient on the size of the government sector is positive and significant in both samples. The coefficient on population growth is significantly positive in the liberalizing sample suggesting that countries with high population growth have higher consumption growth volatility. The primary coefficient of interest in these regressions is the equity market liberalization coefficient. The coefficient is highly significantly negative in the larger sample and not different from zero in the smaller sample. 
The final panel in Table 2 explores the role of time effects. We consider both a time trend variable as well as 16 different year dummy variables. The first specification should control for any trends in overall consumption growth volatility. In fact, there is a large literature in macroeconomics (see, e.g., Blanchard and Simon, 2001; Stock and Watson, 2002) documenting recent decreases in the volatility of real variables such as consumption and GDP growth in the U.S. and other OECD countries. Because of the 0/1 pattern in our liberalization variable, we might spuriously detect a decrease in consumption growth volatility which is simply a result of a decrease in world consumption growth volatility through time. The time dummy specification is more general. It will pick up potential trends and more complex patterns. For example, the time dummy specification should control for world business-cycle effects which are potentially important as recessions tend to be associated with increased real volatility.

The results for the two time specifications are similar. In each of the four regressions, the coefficient on the liberalization indicator is negative. Similar to the regressions without the time effects, the liberalization coefficient is highly significant in the larger sample and insignificantly different from zero in the sample of liberalizers. When we introduce world GDP growth and world real interest rates as additional controls instead of time dummies, the liberalization coefficient is not affected. If we take the $+1 \%$ increase in volatility as the null hypothesis, we reject it in every specification in Table 2 .

\subsection{Capital account openness and growth variability}

So far, we have narrowly focused on equity markets because equity flows are particularly relevant for risk sharing. However, much of the literature describing the adverse effects of capital mobility and financial liberalization concerns all financial markets, with primary emphasis on the banking sector. The recent debate on the effects of capital account liberalization on economic growth (see, for example, Rodrik, 1998a; Edwards, 2001) is a good example. We repeat our regressions including either the IMF or Quinn (1997) capital account openness measure.

Panel A of Table 3 focuses on the IMF measure of openness. While the regression includes the standard control variables and a time trend, we only report the coefficients on the liberalization indicators because the signs and magnitudes of the coefficients on the control variables are generally similar to Table 2 . When the equity market liberalization variable is replaced with the IMF variable, the coefficient is still negative but one-third the magnitude of the equity market liberalization coefficient. The IMF indicator is not significant in the 40 country sample and significant using the asymptotic distribution but not significant using the finite sample distribution for the 95 country sample. In the regression that combines the IMF and equity variables, the results are similar to the regressions that use only a single openness indicator. However, the IMF variable is never significantly different from zero.

The combined regression results suggest that countries with an open equity market and open capital account have about $2 \%$ lower consumption growth volatility than totally closed countries. These results are at odds with the image painted by authors such as Rodrik (1998a) and Agenor (2003) about open capital accounts. It is conceivable that there are benefits to having an open equity market while still maintaining some form of capital controls (for instance on debt flows). Such countries would receive a ' 1 ' for the equity market liberalization variable, but a ' 0 ' for the capital account liberalization measure. Countries in this group include Chile, an often-cited example of a country where capital controls "work." They also include countries such as Botswana, Brazil, Iceland, Mexico and South Africa. There are also a number of countries with open equity markets throughout the sample, where capital account liberalization 
Table 3

Consumption growth volatility and capital account openness (standard controls and time trend)

\begin{tabular}{|c|c|c|}
\hline Panel A: IMF capital account openness & $\begin{array}{l}\text { Sample I } \\
\text { (95 countries) }\end{array}$ & $\begin{array}{l}\text { Sample II } \\
\text { ( } 40 \text { countries) }\end{array}$ \\
\hline IMF capital account openness indicator & $\begin{array}{c}-0.0057 \\
(0.0028)\end{array}$ & $\begin{array}{c}-0.0005 \\
(0.0032)\end{array}$ \\
\hline IMF capital account openness indicator & $\begin{array}{c}-0.0038 \\
(0.0028)\end{array}$ & $\begin{array}{c}-0.0008 \\
(0.0031)\end{array}$ \\
\hline Official liberalization indicator & $\begin{array}{c}-0.0158 \\
(0.0031)\end{array}$ & $\begin{array}{r}-0.0018 \\
(0.0033)\end{array}$ \\
\hline Equity open/IMF capital closed & $\begin{array}{c}-0.0142 \\
(0.0032)\end{array}$ & $\begin{array}{r}-0.0015 \\
(0.0035)\end{array}$ \\
\hline Equity open/IMF capital open & $\begin{array}{c}-0.0223 \\
(0.0038)\end{array}$ & $\begin{array}{r}-0.0032 \\
(0.0045)\end{array}$ \\
\hline Significance & $* * *$ & \\
\hline Panel B: Quinn capital account openness & $\begin{array}{l}\text { Sample I } \\
\text { ( } 76 \text { countries) }\end{array}$ & $\begin{array}{l}\text { Sample II } \\
(37 \text { countries })\end{array}$ \\
\hline Quinn capital account degree of openness indicator & $\begin{array}{r}-0.0266 \\
(0.0045)\end{array}$ & $\begin{array}{r}-0.0185 \\
(0.0072)\end{array}$ \\
\hline Quinn capital account degree of openness indicator & $\begin{array}{r}-0.0226 \\
(0.0049)\end{array}$ & $\begin{array}{r}-0.0190 \\
(0.0076)\end{array}$ \\
\hline Official liberalization indicator & $\begin{array}{r}-0.0037 \\
(0.0026)\end{array}$ & $\begin{array}{c}0.0011 \\
(0.0034)\end{array}$ \\
\hline Equity open/Quinn $\leq 0.5$ & $\begin{array}{c}0.0013 \\
(0.0036)\end{array}$ & $\begin{array}{c}0.0036 \\
(0.0040)\end{array}$ \\
\hline Equity open/Quinn $>0.5$ & $\begin{array}{r}-0.0165 \\
(0.0033)\end{array}$ & $\begin{array}{c}-0.0067 \\
(0.0040)\end{array}$ \\
\hline Significance & $* * *$ & $* * *$ \\
\hline
\end{tabular}

I and II refer to samples of 95 and 40 countries, respectively. The dependent variable is the five-year standard deviation of the real consumption growth rate calculated over 1980-2000. We include in the regressions, but do not report, the same control variables as presented in Table 2, with a time trend. Panel A includes the IMF capital account openness indicator. Panel B includes the Quinn capital account degree of openness indicator; for samples I and II, these regressions include 76 and 37 countries, respectively. Table 1 provides a detailed description for each variable. We also test for the significance of the difference between two openness coefficients in the last regression. Statistical significance is denoted by $1 \%$. All standard errors in parentheses provide a correction for cross-sectional heteroskedasticity and account for the overlapping nature of the data.

occurs later on. This includes several developed markets, such as the European countries that abolished all capital controls because of their participation in the European Union (France, Spain, and Portugal for example). To test this conjecture more directly, the final part of Panel A in Table 3 considers the interaction of the capital account and equity market. We split up the equity liberalization variable into two parts: Equity Open/Capital Closed and Equity Open/Capital Open. The results suggest that the maximum decreased volatility occurs when both the equity market is liberalized and the capital account is open. The difference in the coefficients on these two indicator variables is significant for sample I but not for sample II.

Panel B considers the Quinn (1997) measure of capital market openness. Because the Quinn measure does not cover our full cross-section of countries, we use 76 countries in sample I and 
37 countries in sample II. Using the Quinn measure, capital account openness is associated with significantly lower consumption growth volatility in both samples, although the significance is marginal when we use the finite sample distribution for sample II. The Quinn variable retains its significance when combined with the equity market liberalization variable. In the final part of the panel, we bifurcate the Official Liberalization variable depending on whether the Quinn variable is less than or greater than 0.50. Consistent with Panel A, there are large negative volatility effects of equity market liberalization when the capital account is relatively open, which disappear when the capital account has severe restrictions. The difference between the coefficients on the two indicator variables is significant for both samples. The coefficient on the Equity Open/Capital Open variable is five standard errors below zero for the 76 country sample and 1.7 standard errors below zero in the 37 country sample. There is only one instance where we fail to reject that there is a $+1 \%$ increase in volatility: for relatively closed countries, according to the Quinn measure, equity liberalization increases volatility by 36 basis points (with a standard error of 40 basis points).

The regressions in Table 3 include some countries that had either fully open or fully closed capital accounts during the full sample. To measure the effect of capital account liberalization and to avoid the critique that omitted variables may cause the negative coefficients, we also run regressions of consumption growth volatility on fixed effects and the capital account openness measures. These regressions are comparable to Panel A in Table 2 for equity market liberalization. We find a -0.0023 coefficient for the IMF measure (with a 0.0012 standard error) and a -0.0033 coefficient for the Quinn measure (with a 0.0022 standard error). Hence, our results for capital account and equity market liberalization are qualitatively similar.

\subsection{Robustness}

\subsubsection{Alternative measurement of liberalizations}

In Panel A of Table 4, we measure the impact on consumption growth volatility when replacing the official liberalization indicator with the Intensity variable. Similar to Table 3, we do not display the coefficients associated with the control variables. The Intensity indicator is associated with much stronger decreases in consumption growth volatility than the Official Liberalization variable. For example, in the 40 country sample, the impact of the Intensity indicator is -0.0075 compared to -0.0018 for the Official Liberalization variable. However, its standard error is 0.0040 .

\subsubsection{Stabilizing influence of the government sector}

In Table 2, we found that the size of the government sector is positively correlated with consumption growth volatility. It is conceivable that this hides two results. Less developed countries with poorly developed welfare programs and macroeconomic policies may have positive coefficients because a larger government sector indicates a greater degree of profligacy. Richer countries, facing fewer macroeconomic imbalances, may have negative coefficients with a larger government sector indicating the existence of a better social security network that provides considerable benefits in smoothing income shocks. If this is the case, our regression may be biased as the liberalization effect may perhaps partially proxy for the beneficial effects of a larger government sector in the richer countries. We control for this in two ways.

First, we introduce an interaction term between initial GDP and government size in the basic regression. The results in Panel B of Table 4 show that the interaction is highly significant in both samples and of similar magnitude. In relatively wealthy countries, a larger government sector is associated with lower volatility. For example, in sample II, the estimates imply that 
Table 4

Robustness (standard controls and time trend)

\begin{tabular}{|c|c|c|}
\hline Panel A: Alternative dating & $\begin{array}{l}\text { Sample I } \\
\text { (95 countries) }\end{array}$ & $\begin{array}{l}\text { Sample II } \\
\text { (40 countries) }\end{array}$ \\
\hline Official liberalization indicator & $\begin{array}{r}-0.0162 \\
(0.0030)\end{array}$ & $\begin{array}{r}-0.0018 \\
(0.0033)\end{array}$ \\
\hline Liberalization intensity & $\begin{array}{r}-0.0296 \\
(0.0037)\end{array}$ & $\begin{array}{r}-0.0075 \\
(0.0040)\end{array}$ \\
\hline $\begin{array}{l}\text { Panel B: The impact of the } \\
\text { government sector }\end{array}$ & $\begin{array}{l}\text { Sample I } \\
\text { (95 countries) }\end{array}$ & $\begin{array}{l}\text { Sample II } \\
\text { (40 countries) }\end{array}$ \\
\hline Initial $\log (\mathrm{GDP})$ & $\begin{array}{c}0.0089 \\
(0.0022)\end{array}$ & $\begin{array}{c}0.0129 \\
(0.0033)\end{array}$ \\
\hline Gov/GDP & $\begin{array}{c}1.0030 \\
(0.1097)\end{array}$ & $\begin{array}{c}0.8499 \\
(0.1287)\end{array}$ \\
\hline Initial $\log (\mathrm{GDP}) \times$ Gov/GDP & $\begin{array}{r}-0.0981 \\
(0.0127)\end{array}$ & $\begin{array}{r}-0.0962 \\
(0.0172)\end{array}$ \\
\hline Official liberalization indicator & $\begin{array}{r}-0.0110 \\
(0.0031)\end{array}$ & $\begin{array}{r}-0.0018 \\
(0.0032)\end{array}$ \\
\hline Panel C: Social security & & $\begin{array}{l}\text { Sample I } \\
\text { (58 countries) }\end{array}$ \\
\hline Official liberalization indicator & & $\begin{array}{c}0.0007 \\
(0.0020)\end{array}$ \\
\hline Gov/GDP & & $\begin{array}{c}0.0440 \\
(0.0108)\end{array}$ \\
\hline Official liberalization indicator & & $\begin{array}{r}-0.0021 \\
(0.0020)\end{array}$ \\
\hline Gov/GDP & & $\begin{array}{c}0.0645 \\
(0.0161)\end{array}$ \\
\hline Social security & & $\begin{array}{r}-0.0145 \\
(0.0019)\end{array}$ \\
\hline Liberalization intensity & & $\begin{array}{r}-0.0055 \\
(0.0025)\end{array}$ \\
\hline Gov/GDP & & $\begin{array}{c}0.0467 \\
(0.0097)\end{array}$ \\
\hline Liberalization intensity & & $\begin{array}{r}-0.0117 \\
(0.0029)\end{array}$ \\
\hline Gov/GDP & & $\begin{array}{c}0.0703 \\
(0.0159)\end{array}$ \\
\hline Social security & & $\begin{array}{c}-0.0161 \\
(0.0018)\end{array}$ \\
\hline
\end{tabular}

The dependent variable is the five-year standard deviation of the real consumption growth rate calculated over 1980-2000. We include in the regressions, but do not report, the same control variables as presented in Table 2, including a time trend. Panel A includes the official liberalization indicator and the liberalization intensity measure.

In Panel B, we consider the interaction of the initial level of GDP in 1980 with the government expenditures/GDP ratio. In Panel C, we consider the impact of the social security index. For comparison, the first line shows the liberalization effect in the sample of 58 countries, without including the social security variable. The second group of numbers applies to the regression with the social security index included. Table 1 provides a detailed description for each variable. All standard errors in parentheses provide a correction for cross-sectional heteroskedasticity and account for the overlapping nature of the data. 
this is true for countries with a real GDP per capita of more than $\$ 6836 .{ }^{4}$ The inclusion of the interaction variable increases the magnitude of the liberalization coefficient in the largest sample somewhat but the coefficient is still significantly negative. The coefficient is unchanged in the smaller sample.

Second, in Panel C, we introduce a cross-sectional measure for the extent and quality of the social security system directly into the regression. The social security data are from Botero et al. (2004) and measure: (i) old age, disability and death benefits; (ii) sickness and health benefits; and (iii) unemployment benefits. Because they are available for only 58 countries, we also report the original regression for this particular sample. For this small set of countries, there is no significant liberalization effect. The coefficient on the social security variable is highly significant being more than seven standard errors below zero. The coefficient on the Official Liberalization indicator becomes negative but is only one standard error below zero. We also consider the liberalization Intensity measure. In this case, the coefficient on the social security index is almost nine standard errors below zero. The coefficient on the liberalization Intensity variable, already negative in the original regression, is more than four standard errors below zero. In both cases, adding the social security variable strengthens the liberalization effect. Also note that the coefficient on size of government increases, as expected, as the social security index is introduced.

Whereas we do not report these results, it is the case that both for the standard IMF as for the Quinn measure, controlling for social security makes the liberalization effect significantly negative. This suggests that some countries with closed capital accounts (such as Chile) derive significant volatility benefits from their social security network.

\subsubsection{Regional and common shocks}

If certain regions face similar shocks and liberalizations are clustered in regions with lower volatility, our results may be biased. To deal with this, we introduce regional dummies for Africa, South America, North America and Asia. Not surprisingly, the African dummy is the largest. The magnitude of the liberalization coefficient in the largest sample again increases. However, the coefficient is still significantly negative, albeit only marginally. The coefficient in the smaller sample, while negative, is not significantly different from zero. These results are available on request.

A second experiment we perform is to re-estimate the regression using an SUR estimator that allows residual correlation across countries. The results remain qualitatively and statistically the same and we do not report them.

\subsubsection{Impact of 1997-2000}

In none of the regressions considered so far is consumption growth volatility significantly larger for liberalized countries. This is a remarkable finding given that the sample considered includes 1998, the year for which output and consumption fell dramatically in many emerging economies in the wake of the Asian Crisis. For example, in 1998, real per capita GDP growth was $-12.1 \%$ in Thailand, $-15.7 \%$ in Indonesia, and $-7.8 \%$ in Korea according to the World Bank. The 1998 crises period gave rise to the argument that financial market volatility induced by short-term foreign capital passes through to the real economy (see, for example, Furman and Stiglitz, 1998; Kaminsky and Reinhart, 1999; Gourinchas and Jeanne, 2002). In contrast, our empirical evidence is not consistent with increased consumption growth variability for

\footnotetext{
${ }^{4}$ Calculated as the exponential of $8.83=0.8499 / 0.0962$. The base year for real GDP is 1995 .
} 
emerging economies post-liberalization, and actually is suggestive of reduced economic growth variability for those countries that are liberalized.

We also ran regressions results for the pre-crisis period (1980-1997) (not reported). This period allows us to consider also the effects of equity market liberalization free of the dominating effects of the 1998 crisis. While the 1998 crisis period is obviously important to this debate, the turmoil surrounding these events was extreme and some may view it as an outlier. The precrisis evidence is strongly suggestive of reduced consumption growth volatility. For every sample, the effect of equity market liberalization on the variability of consumption growth is negative and significantly different from zero. For sample II, the significance is only borderline for the Official Liberalization measure. Of course, we cannot be sure that adding new data to our sample will effectively reduce the impact of the crisis years as new crises may occur. For example, the 2002 Argentinean crisis will continue to affect our sample for some time. Similar results hold for output growth volatility.

\subsubsection{Monte Carlo analysis}

Our result is very much dependent on the identification of liberalization with a dummy variable. Whereas we have already controlled for many possible random time patterns in consumption growth volatility that might bias our results, it is still possible that the concentration of liberalizations around particular time periods could lead to spurious results. To investigate this possibility, we conduct a Monte Carlo result on our 95 country sample where we found a $-1.75 \%$ decrease in consumption growth volatility. In the Monte Carlo, we re-run the regression 1000 times while randomizing the liberalization dummy across countries. That is, for each replication, we randomly assign each country a realization out of the 95 possible $\mathrm{Lib}_{i, t}$ realizations in our sample. If there were a systematic bias, the resulting distribution of the $t$-statistic should be biased downward and many of the replications should yield coefficients in the neighborhood of the one we find using the actual liberalization dates. However, this is not the case. It turns out that a coefficient of -0.0175 is very far out in the tails of the distribution (in our 1000 replications, we never obtain a value this low) and the 5\% value for a two-sided test is -0.0064 . The Monte Carlo does reveal that a $t$-statistic of over 3.00 is necessary to obtain $5 \%$ significance in a two-sided test. This result is entirely consistent with the Monte Carlo we ran in Appendix A and is due to the slight under-estimation of the standard errors in the HansenHodrick (1980) procedure (see Hodrick, 1992; Ang and Bekaert, in press for further discussion).

\section{Endogeneity and simultaneity}

To sum up our results so far, we have uncovered that in a large sample of countries, having a liberalized equity market or open capital account is associated with significantly lower consumption growth volatility. When we restrict attention to mostly emerging liberalizing countries, we find that the decision to liberalize the equity market does not usually lead to a significant change in consumption growth volatility. This is also an important result because the literature has mostly assumed that liberalization leads to significant increases in volatility, a hypothesis we can reject.

There are a number of well-known problems with the interpretation of these results. First, because liberalization is a government decision, it is possible that it exactly occurs when volatility is expected to decrease for exogenous reasons. Section 4.1 summarizes analysis that suggests this problem is not driving the results. 
Second, equity market liberalization may occur simultaneously with other reforms and it may be these other reforms that drive the volatility effect. This is also a concern for the weak emerging market results where no volatility effect was detected: other reforms may reduce volatility but the partial effect of opening up capital markets may actually be to increase real volatility. More broadly put, it may be that countries only liberalize when they have good institutions in place to help absorb income shocks, that is, when they have highly developed financial systems, big welfare states, effective macroeconomic policies, etc. Note that we already looked at specifications with fixed effects for the liberalizing sample and that we controlled for the level of economic development in all of our specifications with control variables but this is not likely to suffice. Our approach here is to include a substantial number of controls that may capture simultaneous reforms or the presence of effective institutions to reduce the likelihood of large economic shocks, or improve the ability of agents to smooth these shocks. We first focus on macroeconomic reforms and financial development, then switch attention to the quality of institutions and institutional reform.

\subsection{Endogeneity}

The classic endogeneity problem is much more obvious when one is worried about measuring the mean response to liberalization, because it is possible that countries relax capital inflow constraints when good growth opportunities present themselves. Even though we focus on volatility, it is still useful to examine the determinants of the liberalization decision. For example, governments may institute volatility reducing reforms because they are worried about the increased external risks associated with openness, or the volatility of shocks may have been decreasing prompting liberalization.

Here we summarize the results of a probit analysis of the liberalization decision, more fully described in an earlier draft of this article (see Bekaert et al., 2004). As determinants, the analysis includes economic development measures (the control variables of Table 2), growth opportunity measures, measures of the volatility of shocks, political risk measures, and a financial development measure.

Among the economic development measures, only secondary school enrollment predicts liberalization significantly. An exogenous measure of growth opportunities (see Bekaert et al., 2006 in press for details) is inversely related to the probability of liberalization, suggesting that governments do not time liberalizations strategically or if they do, they do so when growth opportunities are poor. Whereas past GDP growth rate volatility has a negative effect on the probability of liberalization, the effect is insignificant. Inflation variability has no effect on the probability to liberalize. Using the political risk rating from ICRG, we find that political factors are significant for the decision to liberalize. This is consistent with the political science literature where liberalization is mostly viewed as determined by political factors (see, among others, Frieden, 1991; Goodman and Pauly, 1993; Leblang, 1997; Quinn and Inclan, 1997 and the review in $\mathrm{Li}$ and Smith, 2002). Using subcomponents of the political risk rating, we find that the quality of government institutions (see Table 1 for details) drives the positive effect. Lastly, financial development significantly predicts the liberalization decision; perhaps governments liberalize once they have sufficiently developed financial markets to absorb exogenous shocks that may otherwise increase volatility. To mitigate concerns about endogeneity or reverse causality, the next sub-sections control for the (changes in the) political institutions, the quality of institutions, and financial development. 


\subsection{Macroeconomic reforms and financial development}

It is possible that macroeconomic reforms implemented around the time of equity market liberalization diminish macroeconomic imbalances and reduce consumption growth variability. Similarly, simultaneous financial reforms may be the true source of lower variability. Given that portfolios worldwide are still very much biased towards the home market, an efficient domestic financial sector may be more important to smooth aggregate shocks over time than the ability to share risk internationally by investing in foreign equities. Therefore we add three variables to the regression that should be particularly sensitive to macroeconomic reforms (trade to GDP, inflation and the black market premium) and one financial development measure (private credit to GDP). Table 5 reports results for all of our measures of financial liberalization.

Policies aimed at making the economy more open to international trade are typically a cornerstone of macroeconomic reform. When we add the size of the trade sector (imports plus exports to GDP) as a control variable, we consistently find a significant positive relation between consumption growth volatility and the trade sector. This may be surprising at first, but it is conceivable that more open economies are more specialized and hence have larger income shocks. In the face of imperfect capital markets, this external risk may result in higher consumption growth variability. This is exactly the argument Rodrik (1998b) makes and our evidence is consistent with his point. Rodrik also argues that more open economies will have larger government sectors to offset the larger external risk. Note that the positive coefficient survives in our framework despite the presence of the size of the government sector as an independent variable. ${ }^{5}$ Easterly et al. (2001) and Kose et al. (2003) also find that trade openness is associated with high real volatility.

Many macro-reforms are also aimed at controlling inflation so we add the log of one plus the inflation rate for time $t$ to our set of independent regressors. It is not surprising that higher inflation increases the volatility of consumption growth, but it is somewhat surprising that this result is not significant for the liberalizing sample. When we replace the level of inflation with its standard deviation, we find a similar result.

Finally, an often-used measure of macroeconomic imbalances is the black market premium, which we measure as the log of one plus the black market premium for time $t$. Its coefficient in Table 5 is always significantly positive. Countries with severe macroeconomic imbalances face large consumption growth volatility. However, we must be careful in interpreting this result, since the black market premium is highly correlated with capital controls and, hence, with financial liberalizations (see, for example, Bekaert, 1995).

Theoretical work by Aghion et al. (1999) and empirical work by Easterly et al. (2001) suggest that financial development should be associated with lower output volatility. While the coefficient on private credit to GDP is never significantly different from zero, its sign is consistently negative for the liberalizing sample.

The bottom panel of Table 5 reports results for alternative equity liberalization measures and capital account openness. We do not repeat the coefficients for the control variables as they are qualitatively similar to the base case. Generally, the results in Table 6 show that the macroeconomic and financial reform proxies weaken the liberalization effect, increasing the value of the coefficients in both samples. In the 95 country sample, the equity market liberalization coefficient is still 3.7 standard errors below zero, with the magnitude varying between $1.02 \%$ (Official

\footnotetext{
${ }^{5}$ In unreported results, we also estimate a model with trade interacted with the liberalization indicator. The coefficient is negative for both samples and significantly different from zero in the largest sample. Hence, as expected, liberalized economies cope better with external risk, brought about by trade liberalization.
} 
Table 5

Consumption growth volatility, liberalization, and reform (standard controls and time trend)

\begin{tabular}{|c|c|c|c|c|c|c|}
\hline & $\begin{array}{l}\text { Sample I } \\
\text { (95 countries) }\end{array}$ & $\begin{array}{l}\text { Sample II } \\
\text { (40 countries) }\end{array}$ & $\begin{array}{l}\text { Sample I } \\
\text { (95 countries) }\end{array}$ & $\begin{array}{l}\text { Sample II } \\
\text { (40 countries) }\end{array}$ & $\begin{array}{l}\text { Sample I } \\
\text { ( } 75 \text { countries })\end{array}$ & $\begin{array}{l}\text { Sample II } \\
\text { (39 countries) }\end{array}$ \\
\hline Trade & $\begin{array}{c}0.0153 \\
(0.0025)\end{array}$ & $\begin{array}{c}0.0161 \\
(0.0048)\end{array}$ & $\begin{array}{c}0.0149 \\
(0.0025)\end{array}$ & $\begin{array}{c}0.0153 \\
(0.0048)\end{array}$ & & \\
\hline $\log (1+$ inflation $)$ & $\begin{array}{c}0.0218 \\
(0.0041)\end{array}$ & $\begin{array}{c}0.0045 \\
(0.0050)\end{array}$ & & & & \\
\hline $\log (1+b m p)$ & $\begin{array}{c}0.0183 \\
(0.0026)\end{array}$ & $\begin{array}{c}0.0076 \\
(0.0047)\end{array}$ & $\begin{array}{c}0.0180 \\
(0.0028)\end{array}$ & $\begin{array}{c}0.0079 \\
(0.0047)\end{array}$ & & \\
\hline Private credit & $\begin{array}{c}0.0017 \\
(0.0042)\end{array}$ & $\begin{array}{r}-0.0044 \\
(0.0035)\end{array}$ & $\begin{array}{r}-0.0016 \\
(0.0042)\end{array}$ & $\begin{array}{r}-0.0055 \\
(0.0034)\end{array}$ & & \\
\hline Inflation volatility & & & $\begin{array}{c}0.0005 \\
(0.0002)\end{array}$ & $\begin{array}{c}-0.0001 \\
(0.0004)\end{array}$ & & \\
\hline Quality of institutions & & & & & $\begin{array}{r}-0.0585 \\
(0.0108)\end{array}$ & $\begin{array}{r}-0.0205 \\
(0.0102)\end{array}$ \\
\hline Conflict & & & & & $\begin{array}{c}0.0143 \\
(0.0113)\end{array}$ & $\begin{array}{c}0.0211 \\
(0.0108)\end{array}$ \\
\hline $\begin{array}{l}\text { Official liberalization } \\
\text { indicator }\end{array}$ & $\begin{array}{r}-0.0102 \\
(0.0027)\end{array}$ & $\begin{array}{c}0.0004 \\
(0.0026)\end{array}$ & $\begin{array}{r}-0.0116 \\
(0.0028)\end{array}$ & $\begin{array}{c}0.0002 \\
(0.0026)\end{array}$ & $\begin{array}{r}-0.0082 \\
(0.0035)\end{array}$ & $\begin{array}{r}-0.0026 \\
(0.0031)\end{array}$ \\
\hline Liberalization intensity & $\begin{array}{r}-0.0233 \\
(0.0034)\end{array}$ & $\begin{array}{r}-0.0024 \\
(0.0031)\end{array}$ & $\begin{array}{c}-0.0263 \\
(0.0034)\end{array}$ & $\begin{array}{c}-0.0027 \\
(0.0031)\end{array}$ & $\begin{array}{r}-0.0128 \\
(0.0043)\end{array}$ & $\begin{array}{r}-0.0069 \\
(0.0036)\end{array}$ \\
\hline \multirow[t]{2}{*}{$\begin{array}{l}\text { IMF capital account } \\
\text { openness indicator }\end{array}$} & $\begin{array}{c}-0.0031 \\
(0.0025)\end{array}$ & $\begin{array}{c}0.0011 \\
(0.0030)\end{array}$ & $\begin{array}{c}-0.0037 \\
(0.0026)\end{array}$ & $\begin{array}{c}0.0009 \\
(0.0031)\end{array}$ & $\begin{array}{r}-0.0035 \\
(0.0030)\end{array}$ & $\begin{array}{c}-0.0017 \\
(0.0032)\end{array}$ \\
\hline & $\begin{array}{l}\text { Sample I } \\
\text { ( } 76 \text { countries) }\end{array}$ & $\begin{array}{l}\text { Sample II } \\
\text { ( } 37 \text { countries) }\end{array}$ & $\begin{array}{l}\text { Sample I } \\
\text { ( } 76 \text { countries) }\end{array}$ & $\begin{array}{l}\text { Sample II } \\
\text { ( } 37 \text { countries) }\end{array}$ & $\begin{array}{l}\text { Sample I } \\
\text { ( } 67 \text { countries) }\end{array}$ & $\begin{array}{l}\text { Sample II } \\
\text { ( } 36 \text { countries) }\end{array}$ \\
\hline $\begin{array}{l}\text { Quinn capital account } \\
\text { degree of openness } \\
\text { indicator }\end{array}$ & $\begin{array}{c}-0.0217 \\
(0.0047)\end{array}$ & $\begin{array}{c}-0.0118 \\
(0.0072)\end{array}$ & $\begin{array}{c}-0.0232 \\
(0.0047)\end{array}$ & $\begin{array}{c}-0.0131 \\
(0.0073)\end{array}$ & $\begin{array}{c}-0.0247 \\
(0.0047)\end{array}$ & $\begin{array}{c}-0.0174 \\
(0.0072)\end{array}$ \\
\hline
\end{tabular}

I and II refer to samples of 95 and 40 countries, respectively. The dependent variable is the five-year standard deviation of the real consumption growth rate calculated over 1980-2000. We include in the regressions, but do not report, the same control variables as presented in Table 2, including a time trend. Table 1 provides a detailed description for each variable. All standard errors in parentheses provide a correction for cross-sectional heteroskedasticity.

Liberalization) and $2.33 \%$ (Intensity). For capital account openness, a significant effect remains intact when the Quinn measure is used. Whatever the measure of financial liberalization, the liberalization effect is insignificantly different from zero for the 40 country sample.

Because the continuous control variables we introduced may be imperfect proxies for actual reforms, we consider one more test. It is conceivable that financial and macro-reforms occur after a banking crisis, with the equity market liberalization as one small component of the package. However, when we introduce a dummy variable that is set to one after a "systemic or borderline banking crisis" (see Caprio and Klingebiel, 2001), we find that the liberalization coefficient is not affected.

\subsection{Political and institutional factors}

A stable government may be instrumental in ensuring high quality institutions that promote growth and stability. Political factors may play an important role in determining the magnitude 
of the shocks an economy faces and in setting up the institutional framework to help smooth shocks. As we argued before, it is possible that governments only liberalize when such institutional framework is in place.

It is non-trivial to find variables that exhibit the time-series variation that may be critical in controlling for potential biases in our regressions. We turn to the subcomponents of the ICRG political risk measure to construct two new variables: Quality of Political Institutions and Conflict (see Table 1). Political unrest undoubtedly affects the variability of output and consumption and the end of political unrest may be correlated with reforms, including financial liberalizations. When we add these variables to our regressions in Table 5, the Quality of Political Institutions variable is negatively related to consumption growth volatility and the effect is economically large. That is, higher quality government and institutions are associated with lower consumption growth volatility. The coefficient on the conflict variable is surprisingly positive (less conflict is associated with higher variability) but is only borderline significantly different from zero in sample II. The inclusion of these variables increases the magnitude of the coefficient on the liberalization variable for sample I but decreases its magnitude in sample II. This is true for all liberalization measures. For the Intensity and Quinn measures, the liberalization effect is now significantly negative (using asymptotic standard errors) in both samples.

\section{Heterogeneity}

Is the volatility effect from equity market liberalizations different across countries? For example, theories of financial fragility (Furman and Stiglitz, 1998) suggest that a good institutional framework is essential to prevent crises. We have already demonstrated that the openness of the capital account is important in determining the size of the reduction in volatility. We now consider a menu of additional characteristics that might affect the volatility response. We consider variables related to financial development, government provided insurance, macro-variables and the quality of political and legal institutions.

Our method for Table 6 is as follows. In the main regression with control variables, we break up the liberalization indicator variable into three pieces. The first indicator is for countries that are fully liberalized throughout our sample. The second indicator is for liberalizing countries with a lower than median value of the particular characteristic that we are considering. The third indicator is for liberalizing countries with a higher than median value of the characteristic. We also consider the direct effect of the characteristic by adding it to the main regression. By examining the difference between the 'from the low level of the variable' and the 'from the high level of the variable,' we can determine whether the growth volatility response to a liberalization differs across key characteristics. Table 6 also reports the coefficient on fully liberalized countries. This coefficient is always negative and significant. Note that for all characteristics 'high' is good (high development, low risk) and vice versa.

\subsection{Financial sector}

We consider a number of measures of financial development: the size of the banking system, equity market turnover, the size of the equity market, and shareholder protection.

The results in Table 6 show a significant difference between below and above median private credit to GDP countries. Moreover, the countries with more developed banking sectors experience significantly lower consumption growth volatility following a liberalization. Consistent 
with Table 5, the direct effect of banking development on consumption growth variability is not significantly different from zero. For the equity market turnover variable, we only have 50 countries in the analysis. While there is a difference between the low and high turnover countries, neither the difference nor the individual coefficients are significantly different from zero. There is some weak evidence that the size of the equity market (measured by the ratio of market capitalization to GDP) impacts the magnitude of the decrease in consumption growth volatility after a liberalization. Surprisingly, the direct effect of a larger equity market on volatility is positive.

We consider the La Porta et al. (1997) measure of Anti-director Rights which scores shareholder rights based on six different categories (see Table A1). The liberalization impact on consumption growth volatility across countries with above and below average investor protection is marginally significant. However, for countries with poor investor protection, liberalization increases volatility significantly.

\subsection{Insurance through the government sector}

Social security systems may be the most important means of smoothing income shocks in most countries, especially for low income people. Table 6 suggests that liberalizations generate volatility increases (decreases) in countries with relatively poor (good) social security systems, but the individual coefficients are not significant at conventional levels. As shown before, the own effect of the Social Security variable is significantly negative.

We also use the size of the government sector as a proxy for the extent of shock insurance through the government. Here the own effect is positive, however, there is a sharp, significant difference in the liberalization response for large and small government countries. Countries with larger government sectors have more negative volatility responses. Indeed, the coefficient on the large government/liberalization variable is the most negative coefficient in all of Table 6 and is significant at the $1 \%$ level.

\subsection{Extent of risks present in countries}

We use three measures to proxy for the economic and political risks present in the country upon liberalization. For economic risks, we use the ICRG Economic Risk Ratings and also report results more specifically for foreign debt/GDP. Liberalizations may increase the leverage of highly indebted countries further and significantly increase the chances of a crisis. In fact, this argument has been made forcefully by Ranciere et al. (2005), although with respect to overall credit growth. They also claim that a higher probability of a crisis puts countries on a higher growth path. For political risks, we use the Conflict measure we constructed from the ICRG data.

Table 6 shows that countries with higher than median risk ratings experience a drop in consumption growth volatility after liberalizations that is marginally significant whereas lower than median countries experience an insignificant small increase in volatility. The direct effect is large and negative as well so that the economic risk rating seems to capture cross-sectional and time-series variation in the variability of real shocks. Whereas the direct effect of less foreign debt on volatility is negative and significant, countries with more foreign debt experience less volatility post-liberalization than less indebted countries. To interpret the numbers in this table, recall that an increase in the foreign debt index denotes lower levels of foreign debt. None of the coefficients or their difference is significant, however. 
We find a highly significant difference between countries with low and high Conflict. Consumption growth volatility decreases in countries with low Conflict, but there is an insignificant response in countries with a high Conflict measure. The direct effect is insignificantly different from zero.

\subsection{Quality of institutions}

We begin with La Porta et al.'s (1998) Judicial Efficiency variable which is Business International Corporation's measure of the "efficiency and integrity of the legal environment as it affects

Table 6

Why does the volatility effect from equity liberalizations differ across countries? (Standard controls and time trend)

\begin{tabular}{llllll}
\hline $\begin{array}{l}\text { Impact on volatility } \\
\text { resulting from } \\
\text { liberalization }\end{array}$ & $\begin{array}{l}\text { Fully } \\
\text { liberalized }\end{array}$ & $\begin{array}{l}\text { From low } \\
\text { level of } \\
\text { variable }\end{array}$ & $\begin{array}{l}\text { From high } \\
\text { level of } \\
\text { variable }\end{array}$ & $\begin{array}{l}\text { Wald test: Direct } \\
\text { difference } \\
\text { effect of } \\
\text { interaction } \\
\text { variable }\end{array}$ & $\begin{array}{l}\text { Number of } \\
\text { countries }\end{array}$ \\
\hline
\end{tabular}

\begin{tabular}{|c|c|c|c|c|c|c|c|}
\hline \multicolumn{8}{|l|}{ Financial sector } \\
\hline Private credit & $-0.0429^{* * *}$ & $0.0060^{*}$ & $-0.0130^{* *}$ & $* * *$ & -0.0036 & 95 & Yes \\
\hline Turnover & $-0.0077^{* *}$ & 0.0052 & -0.0010 & & $-0.0061^{* * *}$ & 50 & Yes \\
\hline Market Capitalization/GDP & $-0.0089^{* * *}$ & 0.0037 & -0.0021 & * & $0.0041^{* *}$ & 50 & Yes \\
\hline Anti-director rights & $-0.0055^{* *}$ & $0.0121^{* * *}$ & -0.0021 & $* * *$ & $-0.0039^{*}$ & 47 & No \\
\hline \multicolumn{8}{|c|}{ Insurance through government sector } \\
\hline Social security & $-0.0115^{* * *}$ & 0.0048 & -0.0020 & ** & $-0.0417^{* * *}$ & 58 & No \\
\hline Gov/GDP & $-0.0419^{* * * *}$ & $0.0043^{*}$ & $-0.0205^{* * *}$ & $* * *$ & $0.2705^{* * * *}$ & 95 & Yes \\
\hline \multicolumn{8}{|l|}{ Risks present in countries } \\
\hline ICRG economic index & $-0.0323^{* * *}$ & 0.0036 & $-0.0062^{*}$ & $* * *$ & $-0.0542^{* * *}$ & 75 & Yes \\
\hline Conflict & $-0.0318^{* * *}$ & -0.0008 & $-0.0111^{* *}$ & $* * *$ & 0.0027 & 75 & Yes \\
\hline Foreign debt index & $-0.0267^{* * *}$ & -0.0068 & -0.0013 & & $-0.0417^{* * *}$ & 75 & Yes \\
\hline \multicolumn{8}{|l|}{ Quality of institutions } \\
\hline Judicial efficiency & $-0.0117^{* *}$ & $0.0047^{*}$ & $-0.0105^{* *}$ & **** & $0.0354^{* * *}$ & 47 & No \\
\hline Speed of process (combined) & $-0.0281^{* * *}$ & -0.0033 & $-0.0065^{*}$ & & -0.0002 & 69 & No \\
\hline Quality of institutions & $-0.0170^{* * * *}$ & $0.0049^{*}$ & -0.0049 & $* * *$ & $-0.0567^{* * *}$ & 75 & Yes \\
\hline
\end{tabular}

The dependent variable is the five-year standard deviation of the real consumption growth rate calculated over 1980-2000. We include in the regressions, but do not report, the same control variables as presented in Table 2 , with a time trend. For each regression, we separate the liberalization effect for fully liberalized and liberalizing countries. For liberalizing countries, we estimate interaction effects with the financial sector, government sector, country risks, and quality of institution variables; we report the associated impact on consumption growth volatility for a liberalizing country for a low level (below the median of the associated interaction variable for liberalizing countries) and for a liberalizing country at a high level (above the median of the associated interaction variable for liberalizing countries). We also provide the significance of a Wald test, for which the null hypothesis is that the high-low effects are equivalent for $5 \%$ and $* * *$ for $1 \%$. The financial sector variables we consider are the ratio of private credit to GDP, equity market turnover, equity market size, and anti-director (minority shareholders) rights. The government sector variables we consider are the social security index and the size of the government sector. The country risk variables we consider are the ICRG economic risk index, the ICRG political subcomponent measuring conflict, and the ICRG financial risk subcomponent measuring foreign debt exposure. Note that the foreign debt index is scaled so that higher levels of foreign debt are associated with a lower index value.

Finally, the quality of institutions' variables we consider are judicial efficiency, the combined speed of the process to resolve a bounced check or tenant eviction (longer duration implies a lower speed), and the ICRG political subcomponent measuring the quality of institutions. For all ICRG indices, larger values denote improvements. The number of countries for which the interaction variable is available is also provided. Finally, some of the variables are available as time-series, while others are only available in the cross-section; we denote this in the column labelled "time-series available". All standard errors in parentheses provide a correction for cross-sectional heteroskedasticity and account for the overlapping nature of the data. 
business, in particular foreign firms." Countries with greater judicial efficiency generally have larger decreases in consumption growth volatility following liberalizations and this effect is significant. However, the direct effect of this variable is surprisingly significantly positive. Note that this sample only includes 47 countries. When we use an alternative measure of the quality and effectiveness of the legal system, based on the speed with which a bounced check can be cleared and a tenant evicted (see Djankov et al., 2003), we can expand the sample to 69 countries. We still find that legally efficient countries generate larger volatility responses (in absolute value) but the effect is not significant. Furthermore, the direct effect is not significantly different from zero. Our results suggest that the quality of the legal system has little direct effect on the real variability but that it helps in generating beneficial effects to a financial liberalization.

Our final measure focuses on the components of the ICRG Political Risk Rating that are associated with the Quality of Political Institutions. Acemoglu et al. (2002) stress the importance of the institutional environment in explaining cross-country differences in economic development. We find a significant difference in the growth volatility response across high Quality and low Quality of Political Institutions countries. Countries with poor political institutions experience a marginally significant increase in volatility. There is also a very strong direct negative effect to increases in this indicator, consistent with Table 5. The political factors are more important than legal factors in driving consumption growth volatility.

Table 6 shows that the consumption growth volatility response to liberalization may be significantly different depending on the economic, financial, social and political conditions within a country. We find that countries with a relatively well developed banking sector, lack of external or internal conflict, a large government sector, above average economic outlooks, and/or an efficient legal system experience decreased consumption growth volatility after an equity market liberalization; countries with poor investor protection, a small government sector and/or poor quality of political institutions may experience increased volatility.

\section{Risk sharing and growth}

\subsection{Shocks versus smoothing}

A lower consumption growth variability may be the outcome of a lower variability of income shocks or an improved ability to smooth these shocks. We would expect that international capital market openness should primarily reflect the latter. However, the crisis view on financial liberalizations (see Stiglitz, 2000) would suggest that the volatility of shocks may increase. Hence, it is even possible that our zero effect for liberalizers reflects higher shock volatility coupled with a better ability to smooth these larger shocks. To disentangle these effects, we use GDP growth volatility as our measure of the volatility of income and output shocks and focus on its determinants. Furthermore, to directly measure the change in the ability to share and reduce risk, we investigate the determinants of the ratio of consumption growth volatility to GDP growth volatility.

In Bekaert et al. (2004), we report a table summarizing the effects of our various liberalization measures on GDP growth volatility. The results are very similar to the results we find for consumption growth volatility. That GDP growth volatility and consumption growth volatility react similarly to liberalization is analogous to the result in Imbs (2006). He finds that financial integration increases the co-movements between both consumption and GDP growth rates across countries. Our results and his suggest that financial liberalization does not lead to more specialized production structures. 
To find out whether consumers were better able to smooth consumption after equity market liberalizations, we examine the ratio of consumption growth volatility to output growth volatility around a liberalization in Table 7. Panel A shows a significant decrease in the consumptionoutput volatility ratio in all but a single case looking across the two measures of equity market liberalization but neither the IMF nor Quinn (1997) measure of capital account openness impact the volatility ratio. When the capital account openness variables are included in the regression along with the official liberalization variable, the capital account variable is never significantly negative - and is close to significantly positive in the smaller samples. The equity market liberalization variable is always negative and more than two standard errors below zero in three of four cases.

When we split up the equity market liberalization depending on the degree of capital account openness, we always find the coefficient on the Equity Open/Capital Open to be lower than the Equity Open/Capital Closed coefficient. The magnitude of the variable is also quite high. For example, using the Quinn (1997) measure of openness, the Equity Open/Capital Open coefficient is -0.23 and almost four standard errors from zero in the 76 country sample and -0.21 in the 37 country sample. The difference between the Capital Open and Closed coefficients is always significantly different from zero except for the larger sample using the IMF measure.

Because, surprisingly, consumption growth volatility is often larger than GDP growth volatility, it is interesting to examine what variables significantly affect this ratio. The relative volatility of output and consumption growth is one of the big puzzles in the real business-cycle literature (see Backus et al., 1992). We find that the strongest beneficial (negative) effects are economic development (GDP per capita) and secondary school enrollment.

We also revisit the impact of macroeconomic reforms, financial development and government stabilization programs. In both samples, we find a significantly positive association between trade openness and the volatility ratio indicating that countries with relatively open trade sectors have relatively higher consumption-output volatility ratios. This would again appear to confirm the Rodrik hypothesis, but note that government/GDP is included in the regression. Rodrik argues that larger governments are the response to larger external risk. There is no significant relation between the ratio and the inflation variable. However, there is a significantly positive relation between the black market premium and the volatility ratio in the largest sample. We find a strongly negative relation between private credit to GDP and the volatility ratio in both samples (more than five standard errors in the largest sample) indicating relatively advanced financial development is associated with an increased ability to smooth shocks. It is also the case that the Social Security system is associated with a better propensity to smooth. In each of these regressions, the sign on the Official Liberalization indicator remains negative, though it is only significantly so in one of three cases. Importantly, the absolute magnitude of the liberalization effect is somewhat diminished which suggests that our control variables are reflecting important information that coincides with liberalization events.

Given a certain shock volatility, the results in Table 7 suggest that agents were better able to smooth their consumption after equity market liberalizations. There is some, albeit somewhat weak, evidence that opening up other parts of the capital account is not helpful in doing so and may even hurt. In the 40 country sample, the coefficients on both the IMF and Quinn indicator are positive with the IMF coefficient significantly different from zero. This confirms the results in Kose et al. (2003) who claim that the volatility of consumption growth relative to that of income growth has increased for more financially integrated countries. However, they only focus on the IMF measure of capital account openness. 
Table 7

Liberalization and relative consumption-output volatility (standard controls and time trend)

\begin{tabular}{|c|c|c|}
\hline Panel A: Liberalization & $\begin{array}{l}\text { Sample I } \\
\text { ( } 95 \text { countries) }\end{array}$ & $\begin{array}{l}\text { Sample II } \\
(40 \text { countries })\end{array}$ \\
\hline Constant & $\begin{array}{l}-2.6240 \\
(0.7606)\end{array}$ & $\begin{array}{r}-1.5320 \\
(1.3830)\end{array}$ \\
\hline Initial $\log (\mathrm{GDP})$ & $\begin{array}{r}-0.1819 \\
(0.0311)\end{array}$ & $\begin{array}{r}-0.1626 \\
(0.0431)\end{array}$ \\
\hline GOV/GDP & $\begin{array}{c}3.5330 \\
(0.3401)\end{array}$ & $\begin{array}{c}2.6830 \\
(0.5616)\end{array}$ \\
\hline Secondary school enrollment & $\begin{array}{r}-0.3440 \\
(0.1409)\end{array}$ & $\begin{array}{r}-0.7738 \\
(0.2149)\end{array}$ \\
\hline $\log ($ life $)$ & $\begin{array}{c}0.9732 \\
(0.2066)\end{array}$ & $\begin{array}{c}0.7429 \\
(0.3566)\end{array}$ \\
\hline Population growth & $\begin{array}{c}2.4890 \\
(1.3080)\end{array}$ & $\begin{array}{c}2.6400 \\
(3.6130)\end{array}$ \\
\hline Official liberalization indicator & $\begin{array}{r}-0.1827 \\
(0.0507)\end{array}$ & $\begin{array}{r}-0.1007 \\
(0.0734)\end{array}$ \\
\hline Liberalization intensity & $\begin{array}{r}-0.3394 \\
(0.0631)\end{array}$ & $\begin{array}{r}-0.2963 \\
(0.0828)\end{array}$ \\
\hline $\begin{array}{l}\text { Panel B: Liberalization, reform, and } \\
\text { social security }\end{array}$ & $\begin{array}{l}\text { Sample I } \\
\text { ( } 95 \text { countries) }\end{array}$ & $\begin{array}{l}\text { Sample II } \\
(40 \text { countries })\end{array}$ \\
\hline Trade & $\begin{array}{c}0.2311 \\
(0.0435)\end{array}$ & $\begin{array}{c}0.4156 \\
(0.0853)\end{array}$ \\
\hline $\log (1+$ inflation $)$ & $\begin{array}{c}0.0433 \\
(0.0660)\end{array}$ & $\begin{array}{r}-0.0970 \\
(0.0630)\end{array}$ \\
\hline $\log (1+$ bmp $)$ & $\begin{array}{c}0.1406 \\
(0.0465)\end{array}$ & $\begin{array}{c}0.1039 \\
(0.0950)\end{array}$ \\
\hline Private credit & $\begin{array}{r}-0.4374 \\
(0.0828)\end{array}$ & $\begin{array}{r}-0.3543 \\
(0.0914)\end{array}$ \\
\hline Official liberalization indicator & $\begin{array}{r}-0.1044 \\
(0.0496)\end{array}$ & $\begin{array}{r}-0.0312 \\
(0.0648)\end{array}$ \\
\hline
\end{tabular}

Sample I

(58 countries)

Social Security

$-0.1941$

(0.0643)

Official liberalization indicator

$-0.0016$

(0.0530)

\begin{tabular}{lcc}
\hline Panel C: IMF capital account openness & $\begin{array}{l}\text { Sample I } \\
(95 \text { countries })\end{array}$ & $\begin{array}{l}\text { Sample II } \\
(40 \text { countries })\end{array}$ \\
\hline IMF capital account openness indicator & -0.0791 & 0.1317 \\
& $(0.0443)$ & $(0.0829)$ \\
IMF capital account openness indicator & -0.0289 & 0.1769 \\
& $(0.0497)$ & $(0.0887)$
\end{tabular}


Table 7 (continued)

\begin{tabular}{|c|c|c|}
\hline Panel C: IMF capital account openness & $\begin{array}{l}\text { Sample I } \\
\text { (95 countries) }\end{array}$ & $\begin{array}{l}\text { Sample II } \\
(40 \text { countries })\end{array}$ \\
\hline Official liberalization indicator & $\begin{array}{r}-0.1532 \\
(0.0513)\end{array}$ & $\begin{array}{r}-0.1231 \\
(0.0730)\end{array}$ \\
\hline Equity open/IMF capital closed & $\begin{array}{r}-0.1364 \\
(0.0557)\end{array}$ & $\begin{array}{r}-0.1242 \\
(0.0744)\end{array}$ \\
\hline Equity open/IMF capital open & $\begin{array}{r}-0.2416 \\
(0.0693)\end{array}$ & $\begin{array}{r}-0.1886 \\
(0.1466)\end{array}$ \\
\hline Significance & $* *$ & \\
\hline Panel D: Quinn capital account openness & $\begin{array}{l}\text { Sample I } \\
\text { ( } 76 \text { countries) }\end{array}$ & $\begin{array}{l}\text { Sample II } \\
(37 \text { countries })\end{array}$ \\
\hline Quinn capital account degree of openness indicator & $\begin{array}{r}-0.0840 \\
(0.0861)\end{array}$ & $\begin{array}{c}0.0100 \\
(0.1737)\end{array}$ \\
\hline Quinn capital account degree of openness indicator & $\begin{array}{r}-0.1702 \\
(0.0943)\end{array}$ & $\begin{array}{c}0.2255 \\
(0.1766)\end{array}$ \\
\hline Official liberalization indicator & $\begin{array}{r}-0.1193 \\
(0.0547)\end{array}$ & $\begin{array}{r}-0.1572 \\
(0.0799)\end{array}$ \\
\hline Equity open/Quinn $\leq 0.5$ & $\begin{array}{r}-0.1004 \\
(0.0676)\end{array}$ & $\begin{array}{r}-0.1106 \\
(0.0853)\end{array}$ \\
\hline Equity open/Quinn $>0.5$ & $\begin{array}{r}-0.2325 \\
(0.0660)\end{array}$ & $\begin{array}{r}-0.2122 \\
(0.1009)\end{array}$ \\
\hline Significance & $* * *$ & $* * *$ \\
\hline
\end{tabular}

I and II refer to samples of 95 and 40 countries, respectively. The dependent variable is the logged value of the ratio of the five-year standard deviation of the real consumption growth rate to the five-year standard deviation of the real GDP growth rate calculated over 1980-2000. In all cases, we include in the regressions, but do not report, the same control variables as presented in Table 2, including a time trend. Table 1 provides a detailed description for each variable. We also test for the significance of the difference between the two openness coefficients in the last regression. Statistical significance is denoted by a $* *$ or $* * *$ for $5 \%$ or $1 \%$, respectively. All standard errors in parentheses provide a correction for cross-sectional heteroskedasticity and account for the overlapping nature of the data.

\subsection{Idiosyncratic consumption growth variability}

Whereas we have so far focused on total consumption growth variability, the international risk sharing literature mentioned in the introduction focuses on idiosyncratic consumption growth variability as a major component of risk sharing benefits. Most studies are mostly counterfactual exercises in the context of full-fledged general equilibrium models focusing on OECD countries (for example, Cole and Obstfeld, 1991; Obstfeld, 1992; Brennan and Solnik, 1989; van Wincoop, 1994). van Wincoop's (1999) survey suggests that the benefits of perfect risk sharing are quite substantial, and it is likely that they are much larger for emerging markets (see, for example, Obstfeld, 1992, 1995; Pallage and Robe, 2003).

It is unlikely that opening equity markets (or opening capital markets more generally) is a sufficient step to realize the theoretical benefits of perfect risk sharing. For example, markets are incomplete and the proportion of output represented by tradable claims is probably quite small. In addition, only a minority of the population of most countries hold stocks (see also Davis et al., 2000). Our work directly tests the effect of changes in regulations that impact 
the ability to share risk across countries. A related study is Lewis (1996) who regresses consumption growth on idiosyncratic output growth for a large set of countries. Under perfect risk sharing, the coefficient should be zero. Lewis distinguishes between restricted and non-restricted countries using a number of separate measures from the IMF's AREAER, including the capital account restrictions variable that we use above. She finds that the coefficient is significantly lower for unrestricted countries.

To better relate our work to the risk sharing literature, we must eliminate the predictable component in consumption growth and focus on idiosyncratic volatility. In Bekaert et al. (2004), we outline a regressions framework that builds on Athanasoulis and van Wincoop $(2000,2001)$ to accomplish this. The specification has a mean equation on excess growth (country growth minus world growth) and we model the conditional variance of the residual as a linear function of instrument variables, leading to a two equation system to be estimated. The regressions yield positive and significant mean growth effects and volatility results that are entirely consistent with our previous work. For conditional volatility, the coefficient on the equity market liberalization variable is significantly negative in the largest sample and not significantly different from zero in the 40 country sample.

Finally, most of the volatility effect is concentrated in the larger sample. This suggests that liberalizations may substantially increase the global ability to share risk but that the liberalizing countries themselves may not always benefit. To verify this more directly, we created a variable $\mathrm{Lib}_{w, t}$, measuring the fraction of countries that are open. As more and more countries open up, it becomes easier for other countries to share risk internationally. Consequently, the increased integration over time should lead to a downward trend in idiosyncratic consumption uncertainty. Of course, only open countries will benefit. Hence, the regressor is introduced as an interaction effect:

$$
\operatorname{Lib}_{\mathrm{glob}, t}=\mathrm{Lib}_{i, t} \times \operatorname{Lib}_{w, t}
$$

The mean response to this global liberalization measure is significantly positive for both samples. For volatility, we find strongly significant negative effects for sample I and insignificant effects for sample II. Hence, this variable effectively yields similar results to using countryspecific dummy variables.

\section{Conclusions}

In this article, we test a very simple proposition: Do equity market liberalizations increase or decrease consumption growth volatility? Investigating a large cross-section of liberalized and segmented markets and using information before and after liberalization, we establish that volatility did not significantly increase. In many cases, consumption growth volatility decreases significantly. Our investigation did not find one specification whereby consumption growth volatility significantly increased. The maximum decrease in consumption growth volatility is found for countries that liberalize their equity markets at a time when their capital account is relatively open. In fact, capital account openness is not associated with higher consumption growth variability and when measured using Quinn's (1997) adjustments for the degree of openness, it is associated with lower variability. The pure temporal effect of equity market liberalization in a sample of mainly emerging markets is not significant using the regulatory-based Official Liberalization measure. With an alternative measure that corrects for the degree of liberalization the volatility effect is overwhelmingly negative.

The result is robust. We control for time trends, business-cycle variation, and regional effects. When we strip out the predictable part of consumption growth and focus on idiosyncratic 
growth variability, we also find that consumption growth volatility significantly decreases postliberalization in our largest sample and does not increase in the smaller one.

Our results are not likely driven by reverse causality (past volatility does not predict liberalization) and survives the addition of numerous control variables, potentially capturing simultaneous reforms or slow moving institutional changes that may increase a country's ability to absorb shocks. We included variables controlling for macroeconomic reforms, financial development, the extent of the social security system, the quality of political institutions, political unrest proxies, among others.

We also distinguish between shock volatility and the smoothing of shocks. Similar to our analysis of consumption growth volatility, we find no evidence of increased GDP volatility - and considerable evidence of decreased shock volatility after equity market liberalization. We then examine the ratio of consumption growth volatility to output growth volatility. We find that the volatility reductions are larger for consumption than for output implying an increased ability to smooth output shocks after equity market liberalizations. This effect is statistically significant for nearly all of our samples and liberalization definitions.

It is often claimed that liberalizing equity markets leads to excessive economic volatility. Our research suggests that this statement is not supported by the data. This is, of course, a statement about average effects. Our research suggests that if the country is economically fragile, has low quality institutions, and a poorly developed financial sector, equity market liberalization may not reduce real variability at all and may even increase it.

\section{Appendix A. A Monte Carlo experiment}

In this appendix, we explore the small sample properties of our estimator proposed above. To begin, we estimate a simple data generating process for one-year growth rates that will form the basis for our simulations.

\section{A.1. One-year growth and liberalization}

Using one-year growth rates for consumption growth for each country, $y_{i, t+1}$, we estimate the following cross-sectionally restricted specification:

$$
y_{i, t+1}=\alpha_{0}\left(1-\operatorname{Lib}_{i, t}\right)+\alpha_{1} \operatorname{Lib}_{i, t}+\left[\sigma_{0}\left(1-\operatorname{Lib}_{i, t}\right)+\sigma_{1} \operatorname{Lib}_{i, t}\right] u_{i, t+1}
$$

This methodology collects all segmented and all liberalized country years in one bin, and estimates their relative means and volatilities. Hence, we employ both time-series and crosssectional information to estimate four parameters, $\alpha_{0}, \alpha_{1}, \sigma_{0}$, and $\sigma_{1}$. Because this model mainly serves as a data generating process, we ignore potentially predictable components in consumption growth. First, we collect the relevant innovations, $u_{i, t}$, from Eq. (3) for each country in one vector:

$$
\mathbf{u}_{t}=\left[\begin{array}{c}
u_{1, t} \\
\vdots \\
u_{N, t}
\end{array}\right]
$$

where $N$ denotes the number of countries in the sample. Let $\boldsymbol{\Omega}_{t}$ denote the conditional variance-covariance matrix for $\mathbf{u}_{t+1}$ : 


$$
\boldsymbol{\Omega}_{t}=\left[\begin{array}{llll}
\sigma_{1, t} & 0 & \ldots & 0 \\
0 & \sigma_{2, t} & \ldots & 0 \\
\vdots & \cdots & \cdots & \vdots \\
0 & 0 & \cdots & \sigma_{N, t}
\end{array}\right]
$$

SUR effects are ignored across countries. This construction is analogous to a restricted version of a panel estimation with groupwise heteroskedasticity. The country-specific innovation variance, $\sigma_{i, t}$, depends only upon the liberalization indicator for that country; however, the innovation variances within each liberalization regime, $\sigma_{0}$ and $\sigma_{1}$, are assumed constant across time and countries.

The conditional likelihood function for a single time period can be expressed as follows:

$$
l_{t}=-\frac{N}{2} \ln (2 \pi)-\frac{1}{2} \ln \left|\mathbf{\Omega}_{t-1}\right|-\frac{1}{2} \mathbf{u}_{t}^{\prime} \mathbf{\Omega}_{t-1}^{-1} \mathbf{u}_{t}
$$

where $N$ is the number of individual countries. Thus, the log-likelihood function for the full panel $(1, \ldots, T)$ is given by:

$$
L=\sum_{t=1}^{T} l_{t}
$$

This procedure estimates the system in Eq. (3) using quasi-maximum likelihood, computing QMLE robust standard errors as in Bollerslev and Wooldridge (1992).

The results for one-year consumption growth rates over 1980-2000 are presented in Panel A of Table A1. We observe an increase in the average rate of growth, captured in the difference between $\alpha_{0}$ and $\alpha_{1}$, following equity market liberalization of $1.67 \%(1.31 \%)$ in sample I (II). The mean effect is broadly consistent with evidence documented by Bekaert et al. (2001, 2005). Additionally, consumption growth volatility, captured in the difference between $\sigma_{0}$ and $\sigma_{1}$, is reduced by $6.55 \%(1.18 \%)$ in sample I (II). Of course, these estimates do not control for other determinants of volatility (such as economic development), or for predictable components. We now examine the link between these one-year volatility estimates and the five-year standard deviation based measure we use in the empirical work.

\section{A.2. Experimental design and finite sample distribution}

We employ the one-year estimates as the baseline for a Monte Carlo simulation experiment designed to assess the small sample properties of our results based on the five-year standard deviation and to obtain information on the significance of the volatility effects. For our largest sample size of 95 countries over a 20 year period, we conduct a Monte Carlo experiment that fully randomizes liberalization dates consistent with their rate of occurrence in the overall sample. For each Monte Carlo replication, we draw 95 uniform random numbers on the interval 1 to 95 , and randomly assign one of the existing liberalization dummies to each country. We simulate $20 N(0,1)$ random variables, $\tilde{u}_{i, t}$, for 95 countries, and given a simulated liberalization date for each country, generate one-year growth rates according to the estimated specification for consumption growth in Table A1. 


$$
y_{t+1}=0.0058\left(1-\mathrm{Lib}_{i, t}\right)+0.0225\left(\mathrm{Lib}_{i, t}\right)+\left[0.1129\left(1-\mathrm{Lib}_{i, t}\right)+0.0474\left(\mathrm{Lib}_{i, t}\right)\right] \widetilde{u}_{i, t+1}
$$

The equation above gives the alternative hypothesis for the Monte Carlo. Additionally, the growth rate simulation for the null model assumes $\sigma_{0}=\sigma_{1}=0.0936-$ the QMLE based estimate for the observed data under the null (the estimated mean effects are almost identical). This simulation generates growth observations for each time period, with the parameters only depending on whether there is a liberalization or not. In the null model, the liberalization does not change growth volatility; in the alternative model, it decreases growth volatility.

For each replication, we construct the five-year range and standard deviation based measures of growth volatility for each country as we do in the actual data. Then, we estimate the following regression using the GMM based methodology presented in Section 2:

$$
\operatorname{Stdev}_{i, t+k, k}=\delta_{0}+\delta_{1} \operatorname{Lib}_{i, t}+\varepsilon_{i, t+k, k}
$$

Under the null, this procedure provides some indication of the behavior of the $t$-statistics for $\delta_{1}$, as well as any potential biases in the coefficient estimates. We repeat this experiment 1000 times.

Table A1

Volatility and liberalization in a one-year growth model

\begin{tabular}{|c|c|c|c|c|}
\hline \multirow[t]{2}{*}{ Panel B: Standard deviation based regression } & \multicolumn{2}{|c|}{$\begin{array}{l}\text { Null hypothesis: } \\
\sigma_{0}=\sigma_{1}=0.0936\end{array}$} & \multicolumn{2}{|c|}{$\begin{array}{l}\text { Alternative hypothesis: } \\
\sigma_{0}=0.1129, \sigma_{1}=0.0474\end{array}$} \\
\hline & $\delta_{1}$ & $t$-statistics & $\delta_{1}$ & $t$-statistics \\
\hline Mean & $-1.4 \mathrm{E}-04$ & -0.080 & -0.0556 & -32.602 \\
\hline Median & $-2.8 \mathrm{E}-04$ & -0.131 & -0.0554 & -32.414 \\
\hline $2.50 \%$ & -0.0074 & -3.603 & -0.0615 & -37.403 \\
\hline $5.00 \%$ & -0.0061 & -3.003 & -0.0606 & -36.939 \\
\hline $95.00 \%$ & 0.0058 & 2.756 & -0.0508 & -28.375 \\
\hline $97.50 \%$ & 0.0068 & 3.126 & -0.0499 & -27.642 \\
\hline
\end{tabular}

\begin{tabular}{lcc}
\hline Panel A: One-year consumption growth & Full period (1980-2000) \\
\cline { 2 - 3 } & I & II \\
\hline$\alpha_{0}$ & 0.0058 & 0.0102 \\
$\alpha_{1}$ & $(0.0039)$ & $(0.0034)$ \\
$\alpha_{0}$ & 0.0225 & 0.0233 \\
$\alpha_{1}$ & $(0.0020)$ & $(0.0036)$ \\
& 0.1129 & 0.0736 \\
& $(0.0110)$ & $(0.0090)$ \\
& 0.0474 & 0.0618 \\
\end{tabular}

In Panel A, the parameters are from the model (8):

$$
y_{i, t+1}=\alpha_{0}\left(1-\mathrm{Lib}_{i, t}\right)+\alpha_{1} \operatorname{Lib}_{i, t}+\left[\sigma_{0}\left(1-\operatorname{Lib}_{i, t}\right)+\sigma_{1} \operatorname{Lib}_{i, t}\right] u_{i, t+1}
$$

using one-year consumption growth for either 95 (sample I) or 40 (sample II) countries. Estimation is by QMLE, and robust standard errors in parentheses are reported. Panel B reports the quantiles of the empirical distribution under the null and the alternative for the coefficient $\delta_{1}$ in Eq. (9) and its $t$-statistics. The Monte Carlo experiment is fully described in the appendix. 
Panel B of Table A1 presents some relevant percentiles of the empirical distribution for the coefficient and for the $t$-statistic on the liberalization coefficient in the regression, $\delta_{1}$. Under the null model, the median coefficient is -0.0003 and the median $t$-statistic is -0.13 , indicating that estimation bias is not a serious issue. The 2.5 th percentile of the distribution shows a coefficient of -0.0074 , and the 2.5 th percentile $t$-statistic is -3.60 . This statistic is larger (in absolute value) than what would be implied by a standard $t$-distribution, a fact we take into account in our inferences in Section 3.

We also explore the behavior of the coefficient estimates under the alternative hypothesis. In this case, the median coefficient is -0.0554 , with a corresponding $t$-statistic of -32.41 , demonstrating the ability of the volatility measure to capture the liberalization effect inherent in the large difference between $\sigma_{0}$ and $\sigma_{1}$ in the data. In other words, tests based on our regression are likely to have large power. Moreover, there appears to be a small upward bias in the estimate. The data generating process builds in a drop in volatility of $6.55 \%$. Our standard deviation measure on average yields a $5.56 \%$ decrease. We could employ the usual bias correction for the estimation of the standard deviation $(\times \sqrt{5 / 4})$, and this would lead to an estimate of $6.22 \%$ for the volatility difference, closer to the $6.55 \%$ truth. We do not implement this bias correction making our volatility change estimates conservative.

\section{Appendix B. Randomizing liberalization dates}

Because the liberalization dates have a $[0,1]$ pattern, there is a possibility that the liberalization effect reflects the occurrence of a shock happening across liberalizing countries but not accounted for by our control variables. This is especially so because many liberalization dates are bunched in time. Therefore, Table B1, reports the results of a Monte Carlo experiment addressing this bunching problem. We repeat the regression for sample I (95 countries) with the usual control variables and the consumption growth standard deviation data, all taken from the sample, 1000 times. However, for each replication we use randomized liberalization dates. That

Table B1

Monte Carlo analysis of the liberalization effect [standard deviation real consumption growth rate (five-year horizon) 1000 replications]

\begin{tabular}{lcc}
\hline & \multicolumn{2}{c}{ Randomized Liberalization Indicator } \\
\cline { 2 - 3 } & Coefficient & $t$-statistics \\
\hline Mean & 0.0000 & -0.0231 \\
Median & -0.0002 & -0.0941 \\
$2.50 \%$ & -0.0064 & -3.2754 \\
$5.00 \%$ & -0.0054 & -2.7531 \\
$10.00 \%$ & -0.0044 & -2.2064 \\
$90.00 \%$ & 0.0043 & 2.1628 \\
$95.00 \%$ & 0.0057 & 2.8749 \\
$97.50 \%$ & 0.0073 & 3.6908 \\
\hline
\end{tabular}

This table presents evidence from a Monte Carlo procedure (with 1000 replications) that mimics the GMM estimation presented in Table 2, for our largest sample of 95 countries. The dependent variable is the five-year overlapping standard deviation of real per capita consumption. The independent variables are the ones used in Table 2 (with a time trend), but the liberalization variable is randomized using the procedure documented in the text. The weighting matrix we employ in our GMM estimation provides a correction for cross-sectional heteroskedasticity. We present the $2.5 \%, 5.0 \%, 10 \%$, $50 \%, 90 \%, 95 \%$, and $97.5 \%$ percentile for the estimated coefficients and $t$-statistics on the liberalization coefficient. 
is, we take the 95 existing liberalization dummy series and for each replication and for each country randomly draw out of this pool with replacement. If there is a problem due to bunching, the Monte Carlo distribution should show a significant bias. The results are given in Table B1. Both the mean and the median of the coefficients are very close to zero, suggesting unbiasedness. There is a negligible downward bias in the $t$-test of 0.02 . The 2.5 th percentile value for the distribution of the coefficient is a negative 64 basis points, whereas the 2.5 th percentile for the $t$-test is 3.28. These results are largely consistent with the results of the previous Monte Carlo. The estimator is unbiased but the standard errors slightly under-estimate the true standard errors, a result well known from the asset pricing literature (see Hodrick, 1992; Ang and Bekaert, 2006). This means that we must use somewhat higher (in absolute magnitude) critical values than dictated by the asymptotic distribution (around 3.00 for a 5\% test). However, assigning the liberalization date to the right country really matters and the $0 / 1$ pattern of the liberalization dummy does not generate econometric problems.

\section{References}

Acemoglu, D., Johnson, S., Robinson, J.A., 2002. Reversal of fortune: geography and institutions in the making of the modern world income distribution. Quarterly Journal of Economics 117, 1231-1294.

Agenor, P., 2003. Benefits and costs of international financial integration: theory and facts. World Economy 26, 1089-1118.

Aghion, P., Banerjee, A., Piketty, T., 1999. Dualism and macroeconomic volatility. Quarterly Journal of Economics 114 , 1359-1397.

Aizenman, J., Noy, I., 2004. Endogenous financial and trade openness: efficiency and political economy considerations. Working paper, University of California, Santa Cruz.

Ang, A., Bekaert, G., 2006. Stock return predictability: is it there? Review of Financial Studies, in press.

Athanasoulis, S.G., van Wincoop, E., 2000. Growth uncertainty and risk sharing. Journal of Monetary Economics 45, 477-505.

Athanasoulis, S.G., van Wincoop, E., 2001. Risk sharing within the United States: what do financial markets and fiscal federalism accomplish. Review of Economics and Statistics 83, 688-698.

Backus, D.K., Kehoe, P., Kydland, F., 1992. International real business cycles. Journal of Political Economy 100 (4), $745-775$.

Bekaert, G., 1995. Market integration and investment barriers in emerging equity markets. World Bank Economic Review 9, 75-107.

Bekaert, G., Harvey, C.R., 2000a. Foreign speculators and emerging equity markets. Journal of Finance 55, 565-614.

Bekaert, G., Harvey, C.R., 2000b. Capital flows and the behavior of emerging market equity returns. In: Edwards, S. (Ed.), Capital Inflows to Emerging Markets. NBER and University of Chicago Press, pp. 159-194.

Bekaert, G., Harvey, C.R., 2005. A chronology of important financial, economic and political events in emerging markets. http://www.duke.edu/ charvey/Country_risk/couindex.htm.

Bekaert, G., Harvey, C.R., Lumsdaine, R., 2002a. Dating the integration of world capital markets. Journal of Financial Economics 65, 203-247.

Bekaert, G., Harvey, C.R., Lumsdaine, R., 2002b. The dynamics of emerging market equity flows. Journal of International Money and Finance 21 (3), 295-350.

Bekaert, G., Harvey, C.R., Lundblad, C., 2001. Emerging equity markets and economic development. Journal of Development Economics 66, 465-504.

Bekaert, G., Harvey, C.R., Lundblad, C., 2004. Growth volatility and financial liberalization. NBER working paper 10560.

Bekaert, G., Harvey, C.R., Lundblad, C., 2005. Does financial liberalization spur growth? Journal of Financial Economics 77 (1), 3-56.

Bekaert, G., Harvey, C.R., Lundblad, C., Siegel, S. Growth opportunities and market integration. Journal of Finance, in press.

Blanchard, O.J., Simon, J.A., 2001. The long and large decline in U.S. output volatility . Brookings Papers on Economic Activity $135-174$. 
Bollerslev, T., Wooldridge, J.M., 1992. Quasi-maximum likelihood estimation and inference in dynamic models with time varying covariances. Econometric Reviews 11, 143-172.

Botero, J., Djankov, S., La Porta, R., Lopez-de-Silanes, F., Shleifer, A., 2004. The regulation of labor. Quarterly Journal of Economics 119, 1339-1382.

Brennan, M.J., Solnik, B., 1989. International risk sharing and capital flows. Journal of International Money and Finance 8 (3), 359-373.

Caprio Jr., G., Klingebiel, D., 2001. Bank insolvencies: cross-country experience. Working paper 1620, World Bank, Washington, DC.

Cole, H.L., Obstfeld, M., 1991. Commodity trade and international risk sharing - how much do financial markets matter. Journal of Monetary Economics 28, 3-24.

Davis, S.J., Nalewaik, J., Willen, P., 2000. On the gains to international trade in risky financial assets. National Bureau of Economic Research working paper 7796.

Djankov, S., La Porta, R., Lopez-de-Silanes, F., Shleifer, A., 2003. Courts. Quarterly Journal of Economics 118, 453518.

Easterly, W., 2001. Debt relief. Foreign Policy 127, 20-26.

Easterly, W., Islam, R., Stiglitz, J., 2001. Volatility and macroeconomic paradigms for rich and poor countries. In: Dreze, J. (Ed.), Advances in Macroeconomic Theory. Palgrave, New York.

Edison, H., Warnock, F., 2003. A simple measure of the intensity of capital controls. Journal of Empirical Finance 10, $81-104$.

Edwards, S., 2001. Capital mobility and economic performance: are emerging economies different. Unpublished working paper, UCLA.

Eichengreen, B., 2001. Capital account liberalization: what do the cross-country studies tell us? World Bank Economic Review 15 (3), 341-365.

Eichengreen, B., Tobin, J., Wyplosz, C., 1995. Two cases for sands in the wheels of international finance. Economic Journal 162-172.

Frieden, J., 1991. Invested interests: the politics of national economic policies in a world of global finance. International Organization 45, 425-451.

Furman, J., Stiglitz, J., 1998. Economic crises: evidence and insights from East Asia. Brookings Papers on Economic Activity, 1-114.

Goodman, J.B., Pauly, L.W., 1993. The obsolescence of capital controls? Economic management in an age of global markets. World Politics 46, 50-82.

Gourinchas, P., Jeanne, O., 2002. On the benefits of capital market integration for emerging market economies, Unpublished working paper, International Monetary Fund.

Hansen, L.P., Hodrick, R.J., 1980. Forward exchange rates as optimal predictors of future spot rates. Journal of Political Economy 88, 829-853.

Hodrick, R.J., 1992. Dividend yields and expected stock returns: alternative procedures for inference and measurement. Review of Financial Studies 5, 357-386.

Imbs, J., 2006. The real effects of financial integration. Journal of International Economics 68, 296-324.

Kaminsky, G.L., Reinhart, C., 1999. The twin crises: the causes of banking and balance of payments problems. American Economic Review 89, 473-500.

Kose, M.A., Prasad, E.S., Terrones, M.E., 2003. Financial integration and macroeconomic volatility. IMF Staff Papers 50, 119-142.

La Porta, R., Lopez-de-Silanes, F., Shleifer, A., Vishny, R.W., 1997. Legal determinants of external finance. Journal of Finance 52, 1131-1150.

La Porta, R., Lopez-de-Silanes, F., Shleifer, A., Vishny, R.W., 1998. Law and finance. Journal of Political Economy 106, 1113-1155.

Lane, P.R., Milesi-Ferretti, G., 2001. The external wealth of nations: measures of foreign assets and liabilities for industrial and developing countries. Journal of International Economics 55, 263-294.

Leblang, D.A., 1997. Domestic and systemic determinants of capital controls in the developed and developing world. International Studies Quarterly 41, 435-454.

Lewis, K.K., 1996. What can explain the apparent lack of international consumption risk sharing? Journal of Political Economy 104, 267-297.

Lewis, K.K., 1999. Trying to explain home bias in equities and consumption. Journal of Economic Literature 37, 571-608.

Li, Q., Smith, D., 2002. Testing alternative models of capital control liberalization. Policy Studies Review 19, $28-52$. 
Mathieson, D.J., Rojaz-Suarez, L., 1993. Liberalization of the capital account: experiences and issues. IMF Occasional Paper No. 103.

Newey, W., West, K., 1987. A simple, positive semi-definite, heteroskedasticity and autocorrelation consistent covariance matrix. Econometrica 55, 703-708.

Obstfeld, M., 1992. International risk sharing and capital mobility - another look. Journal of International Money and Finance 11, 115-121.

Obstfeld, M., 1994. Risk-taking, global diversification, and growth. American Economic Review 84, $1310-1329$.

Obstfeld, M., 1995. International capital mobility in the 1990s. In: Kenen, P. (Ed.), Understanding Interdependence. Princeton University Press.

Pallage, S., Robe, M., 2003. On the welfare cost of economic fluctuations in developing countries. International Economic Review 44 (2), 677-698.

Prasad, E., Rogoff, K., Wei, S., Kose, M.A., 2004. Effects of financial globalization on developing countries: some empirical evidence. Working paper, International Monetary Fund.

Quinn, D.P., 1997. The correlates of changes in international financial regulation. American Political Science Review 91, 531-551.

Quinn, D.P., Inclan, C., 1997. The origins of financial openness: a study of current and capital account liberalization. American Journal of Political Science 41, 814-845.

Quinn, D.P., Toyoda, A.M., 2003. Does capital account liberalization lead to economic growth?: an empirical investigation. Unpublished working paper, Georgetown University.

Ranciere, R., Tornell, A., Westermann, F., 2005. Systemic crises and growth. Unpublished working paper, UCLA.

Rodrik, D., 1998a. Who needs capital account convertibility? Princeton Essays in International Finance 207, 1-10.

Rodrik, D., 1998b. Why do more open economies have bigger governments? Journal of Political Economy 997-1032.

Stiglitz, J., 2000. Capital market liberalization, economic growth and instability. World Development 1075-1086.

Stock, J.H., Watson, M.W., 2002. Has the business cycle changed and why? Unpublished working paper, Harvard University.

van Wincoop, E., 1994. Welfare gains from international risk sharing. Journal of Monetary Economics 34, 175-200.

van Wincoop, E., 1999. How big are potential welfare gains from international risk sharing? Journal of International Economics 47, 109-235. 